\title{
Heat Pump Water Heater Technology: Experiences of Residential Consumers and Utilities
}

\section{June 2004}

Prepared by:

Barbara G. Ashdown

David J. Bjornstad

Gabrielle Boudreau

Melissa V. Lapsa

Susan Schexnayder

Barry Shumpert

Frank Southworth 


\section{DOCUMENT AVAILABILITY}

Reports produced after January 1, 1996, are generally available free via the U.S. Department of Energy (DOE) Information Bridge:

Web site: http://www.osti.gov/bridge

Reports produced before January 1, 1996, may be purchased by members of the public from the following source:

National Technical Information Service

5285 Port Royal Road

Springfield, VA 22161

Telephone: 703-605-6000 (1-800-553-6847)

TDD: 703-487-4639

Fax: 703-605-6900

E-mail: info@ntis.fedworld.gov

Web site: http://www.ntis.gov/support/ordernowabout.htm

Reports are available to DOE employees, DOE contractors, Energy Technology Data Exchange (ETDE) representatives, and International Nuclear Information System (INIS) representatives from the following source:

Office of Scientific and Technical Information

P.O. Box 62

Oak Ridge, TN 37831

Telephone: 865-576-8401

Fax: 865-576-5728

E-mail: reports@adonis.osti.gov

Web site: http://www.osti.gov/contact.html

This report was prepared as an account of work sponsored by an agency of the United States Government. Neither the United States government nor any agency thereof, nor any of their employees, makes any warranty, express or implied, or assumes any legal liability or responsibility for the accuracy, completeness, or usefulness of any information, apparatus, product, or process disclosed, or represents that its use would not infringe privately owned rights. Reference herein to any specific commercial product, process, or service by trade name, trademark, manufacturer, or otherwise, does not necessarily constitute or imply its endorsement, recommendation, or favoring by the United States Government or any agency thereof. The views and opinions of authors expressed herein do not necessarily state or reflect those of the United States Government or any agency thereof. 
ORNL/TM-2004/81

\title{
Heat Pump Water Heater Technology: Experiences of Residential Consumers and Utilities
}

\author{
Barbara G. Ashdown \\ David J. Bjornstad \\ Gabrielle Boudreau \\ Melissa V. Lapsa \\ Susan Schexnayder \\ Barry Shumpert \\ Frank Southworth
}

June 2004

\author{
Prepared by \\ OAK RIDGE NATIONAL LABORATORY \\ P.O. Box 2008 \\ Oak Ridge, Tennessee 37831-6285 \\ managed by \\ UT-Battelle, LLC \\ for the \\ U.S. DEPARTMENT OF ENERGY \\ under contract DE-AC05-00OR22725
}




\section{CONTENTS}

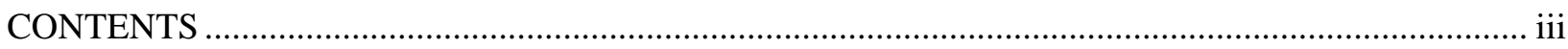

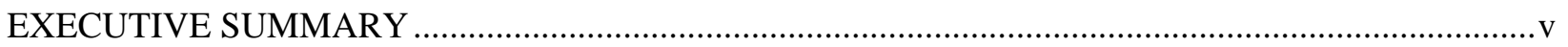

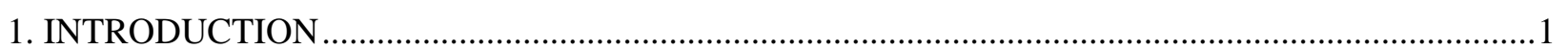

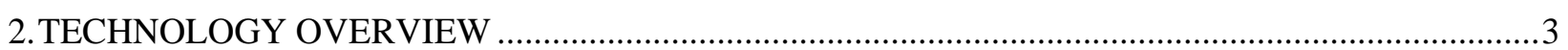

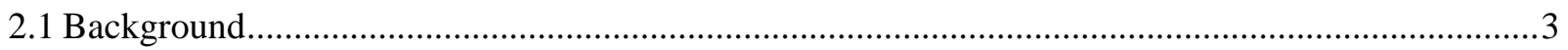

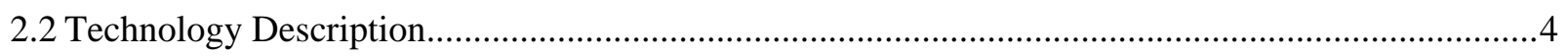

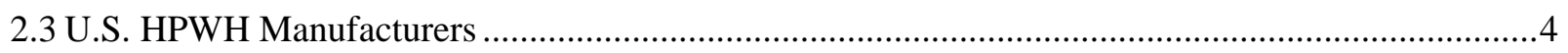

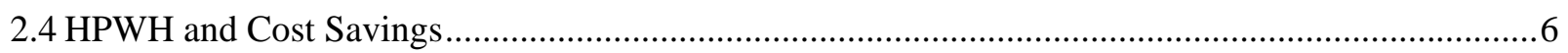

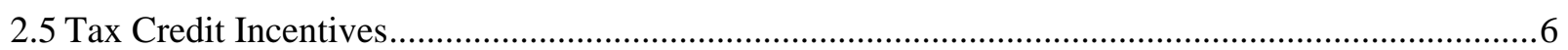

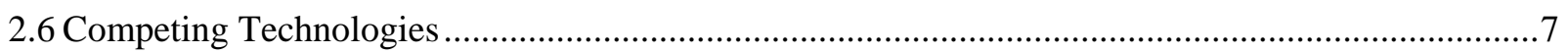

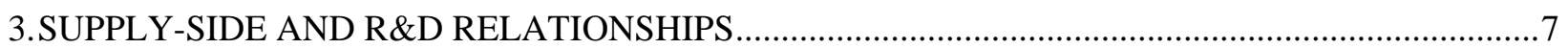

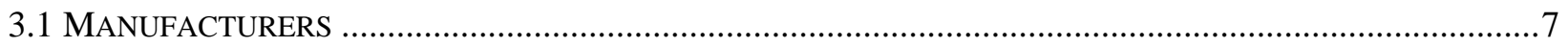

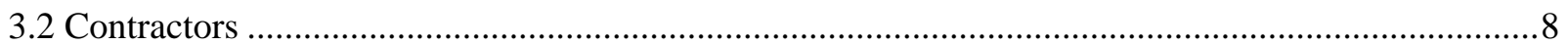

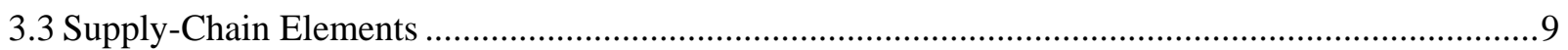

3.3.1 Residential Water-Heater Supply Chains.............................................. 8

3.3.2 Residential Market for Water Heaters.................................................... 10

3.3.3 Water-Heater Manufacture and Supply............................................... 10

3.3.4 Linking Demand to Supply: Wholesale and Retail

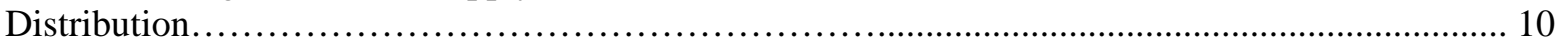

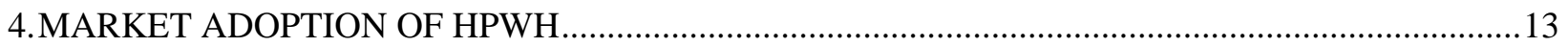

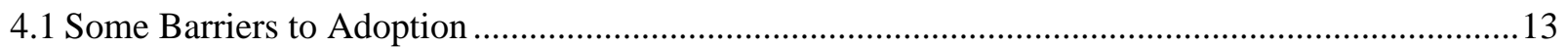

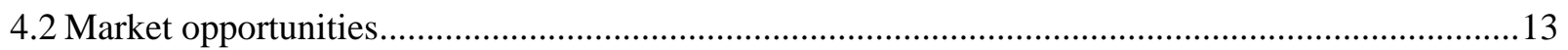

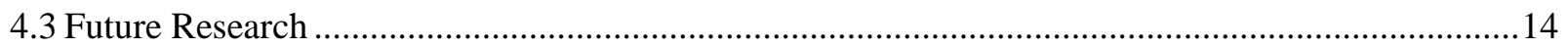

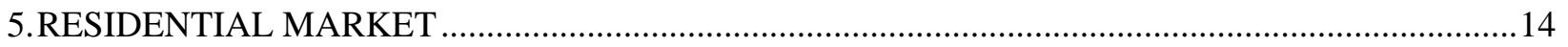

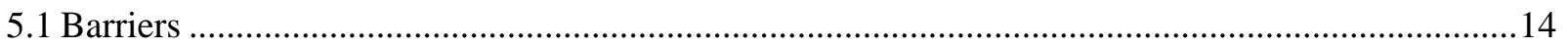

5.2 Recent Findings: Residential Consumers and the HPWH..........................................................15

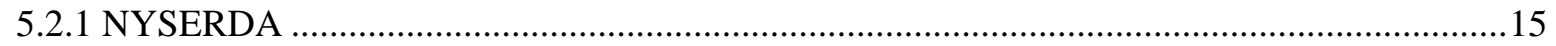

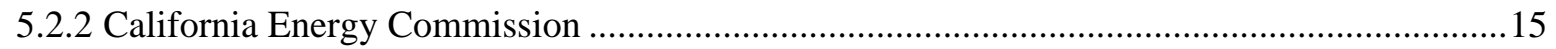

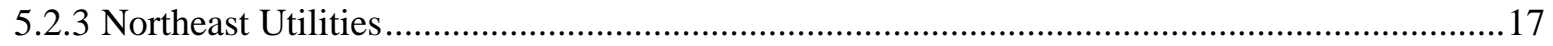

5.2.4 ORNL Focus Group Teleconference Findings ....................................................................18

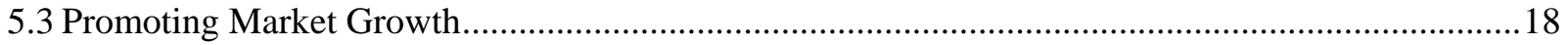

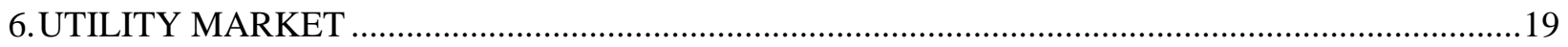

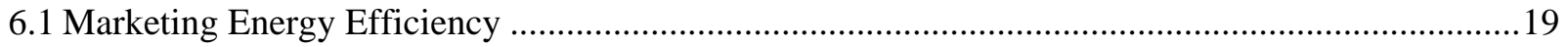




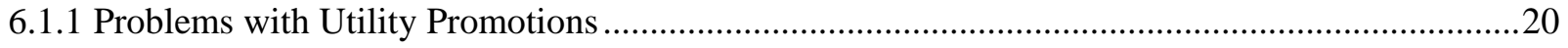

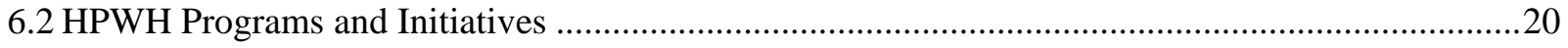

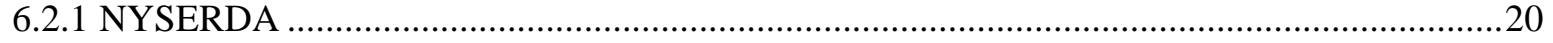

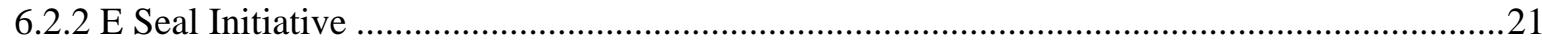

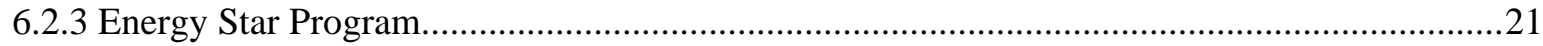

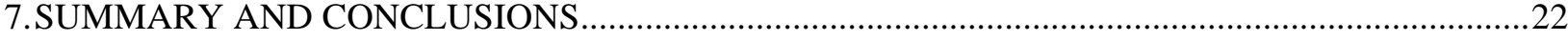

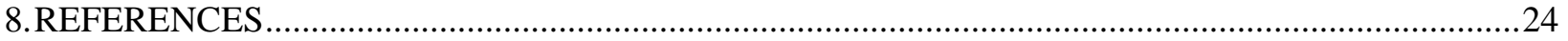

APPENDIX A. UTILITY SURVEY A-1

$\begin{array}{lc}\text { APPENDIX B. ORNL HPWH FIELD TESTS } & \text { B-1 }\end{array}$ 


\section{EXECUTIVE SUMMARY}

This paper presents a case study of the residential heat pump water heater (HPWH) market. Its principal purpose is to evaluate the extent to which the HPWH will penetrate the residential market sector, given current market trends, producer and consumer attributes, and technical parameters. The report's secondary purpose is to gather background information leading to a generic framework for conducting market analyses of technologies. This framework can be used to compare readiness and to factor attributes of market demand back into product design. This study is a rapid prototype analysis rather than a detailed case analysis. For this reason, primary data collection was limited and reliance on secondary sources was extensive.

Despite having met its technical goals and having been on the market for twenty years, the HPWH has had virtually no impact on contributing to the nation's water heating. In some cases, HPWH reliability and quality control are well below market expectations, and early units developed a reputation for unreliability, especially when measured against conventional water heaters. In addition to reliability problems, first costs of HPWH units can be three to five times higher than conventional units. Without a solid, well-managed business plan, most consumers will not be drawn to this product.

This is unfortunate. Despite its higher first costs, efficiency of an HPWH is double that of a conventional water heater. The HPWH also offers an attractive payback period of two to five years, depending on hot water usage. On a strict life-cycle basis it supplies hot water very cost effectively. Water heating accounts

for $17 \%$ of the nation's residential consumption of electricity (see chart at

2001 Residential Buildings Energy End-Use Splits

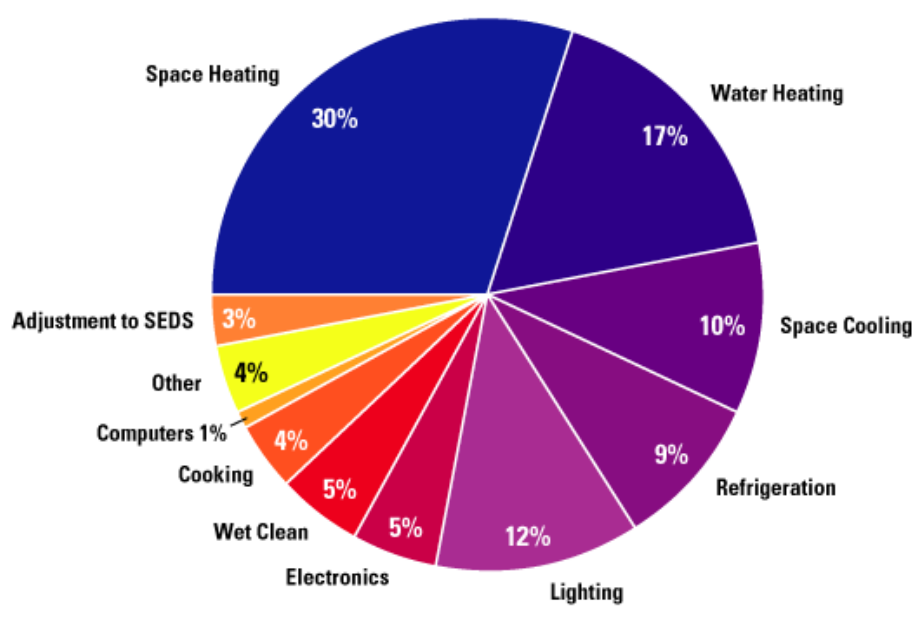

Total Energy Consumption: 20.12 Quadrillion Btu left) — water heating is second only to space heating in total residential energy use. Simple arithmetic suggests that this figure could be reduced to the extent HPWH technology displaces conventional water heating.

In addition, the HPWH offers other benefits. Because it produces hot water by extracting heat from the air it tends to dehumidify and cool the room in which it is placed. Moreover, it tends to spread the water heating load across utility non-peak periods. Thus, electric utilities with peak load issues could justify internal programs to promote this technology to residential and commercial customers.

For practical purposes, consumers are indifferent to the manner in which water is heated but are very interested in product attributes such as initial

first cost, operating cost, performance, Washington, DC, August. serviceability, product size, and installation costs. Thus, the principal drivers for penetrating markets are demonstrating reliability, leveraging the dehumidification attributes of the $\mathrm{HPWH}$, and creating programs that embrace life-cycle cost principles. To supplement this, a product warranty with scrupulous quality control should be implemented; first-price reduction through engineering, perhaps by reducing level of energy efficiency, should be pursued; and niche markets should be courted. 
The first step toward market penetration is to address the HPWH's performance reliability. Next, the manufacturers could engage select utilities to aggressively market the HPWH. A good approach would be to target distinct segments of the market with the potential for the highest benefits from the technology. Communications media that address performance issues should be developed. When marketing to new home builders, the HPWH could be introduced as part of an energy-efficient package offered as a standard feature by builders of new homes within a community.

Conducting focus groups across the United States to gather input on HPWH consumer values will feed useful data back to the manufacturers. "Renaming" and "repackaging" the HPWH to improve consumer perception, appliance aesthetics, and name recognition should be considered. Once an increased sales volume is achieved, the manufacturers should reinvest in $R \& D$ to lower the price of the units. The manufacturers should work with "do-it-yourself" (DIY) stores to facilitate introduction of the technology to these sales venues.

The HPWH is an excellent example of a technology that would have benefited from the implementation of a market research program run in parallel with the technology R\&D program. Understanding consumer values and "willingness to pay" for product attributes and recognizing the corresponding influences those values have on purchase decisions are crucial. This knowledge should be incorporated into the R\&D process with continuous dialogue between the market research and the R\&D programs. Partnerships among stakeholders to gather consumer feedback and market analysis during R\&D will facilitate a strong framework for successful market penetration of energy-efficient technologies. 


\section{INTRODUCTION}

This report focuses on a consumer market analysis project of the energy-saving heat-pump water heater (HPWH) technology. The project, sponsored by the U.S. Department of Energy's Office of Energy Efficiency and Renewable Energy (DOE EERE) and the New York State Energy Research and Development Agency (NYSERDA), was conducted in two phases. In phase 1, we researched market-adoption strategies and effectiveness - how do the utilities support the use and adoption of HPWH technology, and what do consumers value about this technology? In phase 2, we analyzed the complex supply-side elements and R\&D relationships.

A primary goal was to understand the utilities’ perspectives on how their end-use customers would perceive HPWH technology. DOE's Oak Ridge National Laboratory (ORNL) analyzed HPWH and standard water-heater supply-chain elements.

To achieve an understanding of utility perspective on decision criteria and marketing experience regarding energy-efficient technologies, ORNL and the University of Tennessee Knoxville (UT) conducted a survey (Appendix A) of utilities in New York and select utilities nationwide. ORNL also organized a focus group on June 3, 2003, to examine the issues surrounding market adoption of HPWH technology. The group included representatives from several utilities and energy-efficiency organizations; the results of the focus group teleconference are discussed in Section 5.

The survey targeted utility employees responsible for marketing and managing energy-efficient technology to residential customers. The survey sought information about how utilities decide to promote technologies, customer values, the utilities' practices for promoting energy-efficient technologies, current interest in those technologies, and experience with HPWHs and interest in their promotion. The questions were open-ended, but many included prompts. The information was sought to help define appropriate market-adoption strategies for energy-efficient technologies, like the HPWH. The following list summarizes survey results; the survey is included in Appendix A.

- Consumer interest is a decision factor in the promotion of HPWH for most of the smaller New York utilities and the consortia that represent them, suggesting that they are more consumerdriven than the larger New York utilities and the non-New York utilities, none of which identified consumer interest as a decision factor.

- Lowering peak demand was mentioned as a factor by $27 \%$ of the respondents, among them the smaller New York utilities, utility consortia, and non-New York utilities.

- The large non-New York utilities all mentioned their or their regulatory agency's requirement that the technology meet one or more "tests" of appropriateness. These tests include the total resource cost, participant, and societal tests.

- Increased profitability was discussed in two contexts. First, utilities can increase their sales by entering non-regulated markets previously held or dominated by nonelectric service. Second, two utilities mentioned improving revenue by improving load factor in winter.

- A technology's ability to lower utility bills was the attribute most frequently cited by utility customers.

- Familiarity and reliability were more important than other attributes, including energy savings, which two respondents specifically noted was not valued by their customers.

- Nearly half of the respondents do not promote energy-efficient technologies. All but one of these "nonefficiency-promoting" respondents was a New York utility. Respondents explained that NYSERDA assumed the responsibility for DSM and energy-efficiency promotion.

In March 2004, ORNL also conducted an informal survey of seven homeowners who had either owned or had owned an HPWH (see Table 1). Findings from this survey follow Table 1. 
Table 1. Experiences of Residential Consumers

\begin{tabular}{lll}
\hline \multicolumn{1}{c}{ Homeowner's location } & \multicolumn{1}{c}{ HPWH Manufacturer } & \multicolumn{1}{c}{ Length in home } \\
\hline Connecticut & Nyle & 2 years to-date \\
Connecticut & Nyle & 2 years \\
Connecticut & Nyle & 2 years \\
Georgia & ECR & 2 years \\
Alabama & ECR & 2 years to-date \\
Tennessee & ECR & $3 \frac{1}{2}$ years to-date \\
California & ECR & 4 months to-date \\
\hline
\end{tabular}

Initial Cost: All of the homeowners were willing to pay some amount more if other attributes were beneficial to them.

Operating Cost: This was an important attribute for homeowners. Most did not notice a large difference in their utility bill, with the exception of California homeowner, whose monthly utility bill is now a third of what it was before the HPWH, even though the capacity of their tank has increased from 40 to 50 gallons.

Fit in available space: This was an important attribute and affected other attributes (noise level acceptability and benefit from dehumidification).

Dehumidification: In summary, this was the strongest benefit of the HPWH.

Energy Efficiency: In summary, this was as a secondary benefit.

Noise: Most noted a noticeable noise level if the location of the unit was near functional space for the homeowner.

Product reliability: This was an important attribute for all homeowners. All had experienced some problems with the product, mostly with the board, and these had been fixed. Of those who experienced more than one service need, some opted to have the unit replaced with a standard water heater.

Performance: Most did not indicate a difference of performance between the standard water heater and the HPWH with the exception of units having board problems (hot water was then not delivered as needed).

Serviceability: This was an important attribute for all homeowners. All had experience needing service to their HPWH but were satisfied with the service provided. Of those who experienced more than one service need, some opted to have the unit replaced with a standard water heater.

Warranty: The length of the product warranty was not well known by homeowners.

Rebate: For the three homeowners who were not part of a field test study, a rebate was the incentive for purchasing the unit in two of the three.

Other: One homeowner's unit had a control on the exterior of unit which was worrisome with a toddler in the home.

In summary, most homeowners experienced the most benefit from the dehumidification attribute of the HPWH and did not notice a performance difference between the HPWH and the standard water heater except when the HPWH board was not functioning properly. 


\section{TECHNOLOGY OVERVIEW}

\subsection{BACKGROUND}

The HPWH has been on the residential market for twenty years. Currently there are three U.S. manufacturers with two different types of HPWHs on the market: ECR International, Nyle Corp., and Applied Energy Recovery Systems.

Price is a difficult issue. Typical first cost for early HPWH models was $\$ 1400$ or more for a complete installation versus $\$ 400-\$ 450$ for an electric water heater. Depending on installation conditions, payback periods for the incremental cost can be as little as two years (CEE Market Transformer News 2002). Until there is a larger market for HPWHs, their price cannot be significantly lowered.

Furthermore, they will not be picked up by large "do-it-yourself” (or DIY) stores, will not receive "Energy Star" labeling, and will not be widely advertised.

Currently, E-Tech has two models, WH-6 (\$895 plus shipping) and R-106K (\$1100 plus shipping). These models are being sold but not heavily marketed via the current distribution network. Marketing efforts are focused on E-Tech's commercial HPWHs. Nyle has stopped producing its current HPWHs due to low sales volume but has two new models it plans to introduce nationwide. One model is a 110 -volt HPWH with a smaller total cost because it can be installed by the homeowner. The other model is a 240-volt HPWH. These units will cost approximately \$900. ECR's drop-in HPWH costs approximately $\$ 1200$ (without installation) and carries a 7-year warranty. An electric water heater's average lifespan is 11 years; a gas water-heater's, 8 years (DOE-EERE 2003).

The integrated, “drop-in” HPWH unit was employed in the field tests described in Field Testing of a "Drop-In" Residential HPWH, (Murphy and Tomlinson 2002). Testing was conducted in selected laboratory environments under an accelerated cycling scenario to simulate ten years of residential use in less than a year of testing (Baxter and Linkous 2002). A second group of 18 similar units was delivered to ORNL for field-testing. Data received on 16 units installed in homes are also described in the report. The results of these field tests are discussed in more detail in Appendix B.

Only a few hundred HPWHs have been sold nationwide (outside of utility programs), mostly from sales managers marketing to builders in new subdivisions and homeowners investigating the technology via the Internet. Each company now sells the product via their own distribution channels using existing sales reps whose main business is other products. HPWHs, which are not well stocked in distribution centers, are made to order and usually transported on demand. To achieve a significant market, the HPWH must penetrate the replacement market for water heaters. Table 2 shows water heater manufacturers' market shares (conventional water heaters and HPWH) by percentage of products produced.

Table 2. 2001 Water Heater Manufacturer Market Shares (by percentage of products produced)

(Source: Appliance Magazine. A Portrait of the U.S. Appliance Industry, Sept. 2002)

\begin{tabular}{ccc}
\hline Company & Market Share (\%) & Total Units Shipped \\
\hline Rheem Manufacturing & 41 & \\
State Industries & 18 & $9,264,484$ \\
American Water Heater & 14 & \\
Bradford-White & 14 & \\
A.O. Smith & 13 \\
\hline
\end{tabular}




\subsection{TECHNOLOGY DESCRIPTION}

HPWHs take heat from the surrounding air and transfer it to the water in the tank, unlike conventional water heaters, which use either gas (or sometimes other fuels) burners or electric resistance heating coils to heat the water.

HPWHs are more expensive than most conventional water heaters, however, the energy savings can be as much as 50 percent, and the pay-back period can be relatively quick (Chili Pepper Appliance website 2004).

Technically, HPWH technology uses a standard heat pump thermodynamic cycle to remove energy from a low-temperature heat source (the ambient room air) and transfer it to a high-temperature heat sink (the water within the heater).

The heat pump works by taking heat from the surrounding air and using it to heat low-pressure liquid refrigerant in the heat pump's evaporator, vaporizing the liquid. The refrigerant then passes through the compressor, which raises the refrigerant pressure and thus the temperature as well. The heated refrigerant gas passes through the heat pump condenser, where it gives off its heat to the water in the water heater and condenses back into the liquid state. The cooled liquid refrigerant now passes through an expansion valve where the pressure is reduced and the cycle starts over.

This is the same principle as refrigerators, freezers, and room air conditioners, but in reverse. Much less energy is required to "move" the heat than to actually heat the water unless the surrounding air temperature is very low.

Most HPWHs have back-up heating elements to heat the water during very low temperature periods and come either self-contained with a storage tank or as an add-on unit using a conventional water heater for storage.

Typical HPWHs consume one-half to one-third as much electricity as a typical electric water heater. They heat water more slowly than electric or gas water heaters, usually about 15 gallons per hour.

\subsection{U.S. HPWH MANUFACTURERS}

ECR International is selling a stand-alone, “drop-in” HPWH (Watter\$aver) that can be purchased to replace an existing water heater (Fig. 1 shows the savings that can be realized through use of Watter\$aver HPWH at different electricity costs). Nyle Corp. and Applied Energy Recovery Systems (E-Tech product line) produce and sell "add-on” HPWHs that connect to existing water heaters to save energy and provide dehumidification. 
ECR International's Watter\$aver: Estimated Annual Savings

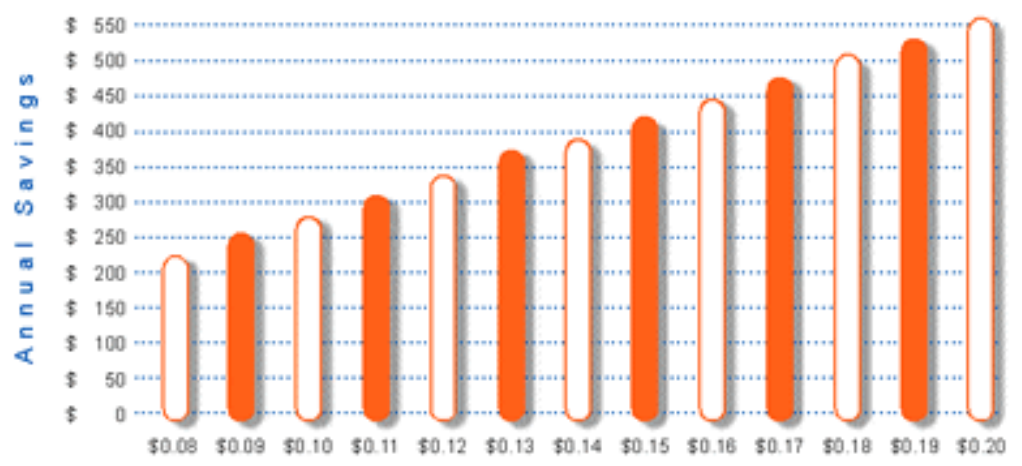

Fig. 1. Electricity Cost Per kW Hour, based on 64.3 gallons per day usage (DOE national average). Source: ECR International (http://www.dunkirk.com/products_wattersaver.asp)

\section{ECR International and NYSERDA}

ECR manufactures the Watter\$aver, achieves more than 50\% energy savings compared to conventional, electric resistance water heaters. A conventional, electric resistance water heater with an Energy Factor (EF) of 0.90 uses about $5000 \mathrm{kWh}$ per year for a typical family of four. The WatterSaver has an EF of 2.4 and only uses about 2000 to $2500 \mathrm{kWh}$ per year. This translates into savings of about 2500 to $3000 \mathrm{kWh}$ per year for a typical family of four. It also achieves demand savings of about $0.5 \mathrm{kWh}$ during summer peak-load conditions. For more information see: http://www.ecrinternational.com/prod_wattersaver.asp

The WatterSaver offers:

- The reliability and noise level of a household refrigerator;

- Simple maintenance;

- 7-year warranty on tank and heat pump;

- Energy factor (EF) of 2.4;

- Typical payback in 2 to 5 years depending on cost of electricity, water heating load, effect on space heating load (electric heat), based on incremental replacement cost versus standard 50gallon electric water heater; 9 cents/kWh and 64.3 gal/day equals (just over 3-year payback).

In New York, ECR has been working closely with NYSERDA to promote HPWHs through incentive programs and informational training workshops for contractors. However, even with the incentive, an HPWH still costs more than a standard water heater. Although NYSERDA's current market-based HPWH program will expire in April 2004, NYSERDA is reevaluating the program while continuing to work with ECR. A manufacturer buy-down strategy is being considered; but there is still concern that savings might not be passed on to consumers. To ensure that customers benefit, some new partnership arrangements, promotional marketing, and educational activities are being considered.

ECR is also reviewing the European and Asian markets for the HPWH. There are European HPWH products on the market, and ECR does have a distribution system overseas. However, the compressor must be modified from 60 cycles to 50 for the ECR “drop-in” to work in these markets. Rheem Australia is marketing a HPWH that retails at AU\$3,750 (US\$2592), with a rebate of AU\$1,350 (US\$933) (Rheem 2003) (www.seav.vic.gov.au/renewable\%5Fenergy/shw_rebate/shw_list.html). 


\section{Applied Energy Recovery Systems (E-Tech)}

E-Tech sells two models of HPWHs: WH-6 (\$895 plus shipping) and R-106K (\$1,100 plus shipping). Marketing efforts, though not intense at this time, are focused on the commercial sector. E-Tech has requested that the ORNL team visit their facilities in Georgia and discuss market adoption strategies. The company is currently revisiting its marketing strategy for the residential HPWH and will focus on the end-user and DIY stores as distribution venues where homeowners and contractors shop. E-Tech summarized the barriers to current market deployment as a lack of knowledge about the technology on the part of contractors, utilities, and homeowners; for this reason, E-Tech is revisiting and refocusing its HPWH marketing strategy. For more information on E-Tech, see:

http://www.aeretech.com/heatpump.html.

\section{Nyle Special Products}

Nyle halted production of its HPWHs due to low sales volume but has two new models (110-volt and 240 -volt HPWHs). Priced at approximately $\$ 900$, the new product has a less expensive total cost because a homeowner can install it him/herself. Nyle is currently developing its distribution network nationwide for these HPWHs and will be working with its distributors to market the product directly to the end-users. For more information on Nyle, see: http://www.nyletherm.com/waterheating.htm.

\subsection{HPWH AND COST SAVINGS}

Water heating is the third largest energy expense in the United States, accounting for about 15 percent of electricity and 25 percent of gas consumption. Figure 2 demonstrates graphically the amount of

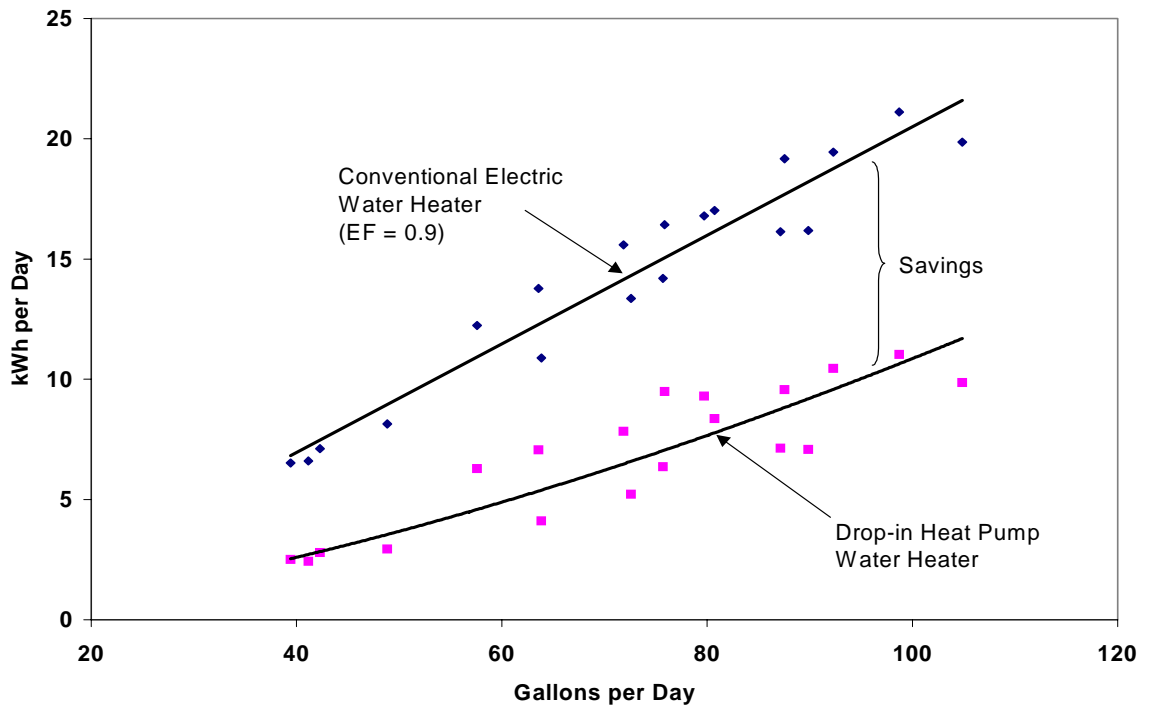

Figure 2. Performance of the drop-in residential heat-pump water heater compared with that of a conventional electric-resistance water heater (ORNL). daily energy savings that were achieved in a recent HPWH field test.

"Properly applied, HPWHs save energy in almost every situation. Initial investment is recouped fastest if electric rates and hot water usage are high and there is a steady need for the cool air generated as a byproduct. HPWHs have difficulty being cost effective when low-

cost natural gas is available. Best energy savings are accomplished when temperatures are mild or warm. Because HPWH efficiency and capacity drop as temperature drops, avoid applications where the ambient air is cold” (PNNL 1995).

\subsection{TAX CREDIT INCENTIVES}

As part of a 2002 Omnibus Energy Bill, tax credits of $\$ 75$ per unit were proposed to consumers on purchases of electric HPWHs. The Sustainable Energy Coalition recommended substituting the Kerry-Snowe-Bingaman proposal, which provided a credit of $\$ 150$ for HPWHs. H.R.6, as passed, is 
the House version of the Energy Policy Act of 2003. It contains no provisions for HPWHs, but the Senate version, S. 597, has the \$75-per-unit tax credit provision. (PR Newswire 2002.)

According to Steven Nadel of ACEEE, a coauthor of the report, "Tax Incentives for Innovative Energy-Efficient Technologies” (www.aceee.org/energy/e013full.pdf), the energy conservation tax credits of the 1970s went to well-known and widely used technologies, resulting in a high proportion of "free-riders" and limited net benefits. The proposed new tax credits for advanced technologies will spur investments that would not otherwise take place. Once these technologies become common, the tax credits should be discontinued.”

The report examined the near- and long-term economic and energy-savings benefits to be achieved through the use of tax credits for selected energy-efficiency measures under consideration by the U.S. Congress in 2001 (including HPWHs). In addition, the study estimated that a total energy savings of approximately 70 Quads would be expected from advanced technology equipment installed by 2020 (the United States used approximately 100 Quads in 2000).

"By "priming the pump" of technological progress, these tax credits foster real changes in consumer choice, product cost, and market competitiveness, providing a powerful market stimulant for these new technologies. “ The package of 12 tax incentives yields a 2.3-to-1 benefit-cost ratio overall, a net benefit of $\$ 110$ billion to the nation, and 9.6 million BTUs of energy savings per dollar of federal investment.” (Energy Conservation News 2001)

Modest federal tax credits have been proposed, but not yet enacted—only two states, Hawaii and Minnesota, have enacted tax-based incentives. Hawaii provides a state tax credit of $20 \%$ of system cost subject to a maximum depending on the application. Minnesota has enacted a sales tax exemption for energy-efficient products sold between August 1, 2001, and July 31, 2005. Products include the electric HPWHs.

\subsection{COMPETING TECHNOLOGIES}

Solar-water-heating systems are an energy-saving alternative to HPWHs. Installing a solar-waterheating system costs more than conventional electric or heat pump installations, but like heat pumps, offer energy saving returns. They are a well-established technology and may offer a more proven track record of reliability and cost savings. Different types of systems are used in different climates, providing freeze protection when necessary and maximizing the system's performance. Most solar systems pay for themselves in energy savings in six to ten years (Knight Ridder/Tribune News Service 2003).

While they offer energy efficiency, solar water heaters are more expensive to install and maintain. They are extremely economical to operate, but most people are still waiting for the cost to decrease further. Government subsidies are making a comeback, which accounts for the recent renewed interest in solar water heaters.

\section{SUPPLY-SIDE AND R\&D RELATIONSHIPS}

\subsection{MANUFACTURERS}

There are numerous manufacturers of commercial HPWHs for commercial applications (restaurants, laundries, hotels, and schools). Table 3 lists the three U.S. manufacturers of residential HPWHs. 


\begin{tabular}{|c|c|}
\hline \multicolumn{2}{|c|}{ Table 3. U.S. Manufacturers of Residential HPWHs } \\
\hline $\begin{array}{l}\text { Applied Energy Recovery Systems, Inc. } \\
6670-A \text { Corners Industrial Court } \\
\text { Norcross, Georgia USA } 30092 \\
\text { Telephone: 770-734-9696 } \\
\text { FAX: 770-453-9323 } \\
\text { Web Site: http:// www. aeretech.com }\end{array}$ & $\begin{array}{l}\text { Products: HPWH systems, pool heater } \\
\text { dehumidifiers, dehumidifiers, commercial pool } \\
\text { heaters, specialty air conditioners. } \\
\text { Note: Applied Energy Recovery Systems acquired } \\
\text { E-Tech which was previously owned by } \\
\text { Crispaire. E-Tech has been a major seller to the } \\
\text { military. E-tech is an add-on HPWH that does } \\
\text { not include a storage tank. It is intended to be } \\
\text { attached to the customer's existing electric } \\
\text { water heater, or to a newly installed water } \\
\text { heater. }\end{array}$ \\
\hline $\begin{array}{l}\text { ECR International, Inc.* } \\
\text { EnviroMaster International LLC } \\
5780 \text { Success Drive } \\
\text { Rome, NY } 13440 \\
\text { Tel: } 800.228 .9364 \\
\text { Fax: } 800.232 .9364 \\
\text { Email: retroaire@enviromaster.com } \\
\text { Web: www.enviromaster.com/watter_saver/ }\end{array}$ & $\begin{array}{l}\text { ECR International's Watter\$aver is the only } \\
\text { "Integral HPWH" that uses a drop-in tank for } \\
\text { easier installation. These units come ready to } \\
\text { install, like a traditional water heater. The heat } \\
\text { pump is permanently attached to the top of the } \\
\text { tank. Similar units have been manufactured in } \\
\text { the past by EUS-Temcor and by DEC-Thermastor. } \\
\text { The Watter\$aver is manufactured and } \\
\text { distributed through these ECR International } \\
\text { divisions: } \\
\text { Dunkirk Boilers, phone: } 877.386 .5475 \text {, fax: } \\
716.366 .1209 \\
\text { EMI, phone: } 800.228 .9364, \text { fax: } 800.232 .9364 \\
\text { Utica Boilers, phone: } 800.325 .5479, \text { fax: } \\
\text { 315.797.3762 }\end{array}$ \\
\hline $\begin{array}{l}\text { Nyle Special Products* } \\
242 \text { Miller St. } \\
\text { Bangor, Maine USA } 04401 \\
\text { Telephone: } 207.942 .2865 \\
\text { FAX: } 207.942 .2859 \\
\text { http:// nyletherm.com }\end{array}$ & $\begin{array}{l}\text { Nyle manufactures and sells heat pumps, water- } \\
\text { heating systems, and energy-efficient } \\
\text { appliances. } \\
\text { Their HPWH, Nyletherm-1, is an add-on HPWH } \\
\text { without a storage tank, intended to be attached } \\
\text { to the customer's existing electric water heater } \\
\text { or to a newly installed water heater. }\end{array}$ \\
\hline
\end{tabular}

\subsection{CONTRACTORS}

Contractors are a key piece of the promotional puzzle for the adoption of energy-efficient technologies like HPWHs. However, they must first be trained to properly install and service them. NYSERDA held a workshop to teach contractors how their customers can potentially save up to $60 \%$ on their monthly water-heating bill. The attendees learned about the program requirements, including how to participate; how to better position their business through the sale of energy-efficient products such as a HPWH; and all the installation, operation, and maintenance requirements of the HPWH. 
Only contractors attending the workshops were eligible to participate in the program and benefit from the incentives. Monetary incentives were given to both the consumer and contractor installing the system (contractors could receive \$100 per system installed) (NYSERDA 2002).

\subsection{SUPPLY-CHAIN ELEMENTS}

\subsubsection{Residential Water-Heater Supply Chains}

The following is a description of the major players involved in getting a working water heater built, delivered, and installed in a U.S. residence. An understanding of how these different players interact with one another to create a water-heater industry supply chain is useful in promoting and marketing new and energy-efficient water-heater technology. The discussion is framed around three key issues that need to be resolved to ensure cost-effective management of any product supply chain (Barbour et al. 1996, ORNL 2002):

- Who are the key supply-chain members?

- What processes should be linked with each of these members?

- What level of management integration should be applied to each link?

The following list names the principal players in the supply chain (see Fig. 3):

- the manufacturers and their parts suppliers;

- plumbing wholesalers, large retailers and other water-heater distributors who receive, store, and sell these heaters to installers;

- plumbing contractors, who in turn work with builders and homeowners to install the appliances;

- residential builders, who typically purchase appliances from these contractors/installers; and

- homeowners.

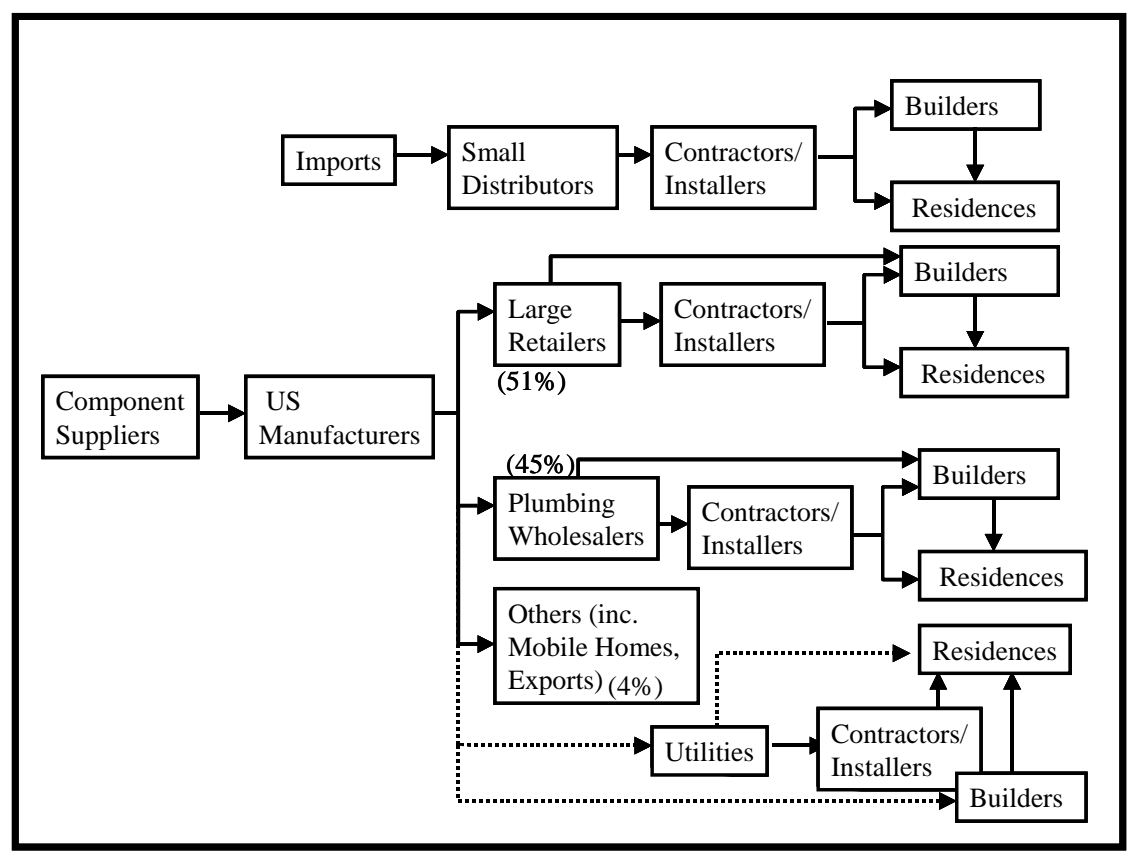

Other important players in the supply chain are the local utility or cooperative, as well as state and federal government, where each provides educational and/or financial support for the adoption of energy-efficient residential water heaters.

This supply chain (Fig. 3) includes installation of water heaters in both existing and new homes, replacement water heaters being the majority of the annual U.S. market. Parts suppliers, plumbing contractors, and installers also do an active business in parts service and repair that are not depicted in this diagram.

Fig. 3. Links in residential water-heater supply chain. 


\subsubsection{Residential Market for Water Heaters}

Hot-water heating accounts for $20 \%$ or more of an average U.S. household's annual energy costs. By year 2000, there were more than 115 million units of housing in the United States, including slightly fewer than 2 million new home completions during the year. The majority of U.S. single-family residences are built by small firms (sole proprietorship and 1-4 employees) and medium-sized firms (5-19 employees). In 1997, there were about 470,000 single-family homebuilding firms in the United States. About $70 \%$ of these firms were sole-proprietor operations accounting for $15 \%$ of the nation's annual construction by dollar value. Ninety-three percent of U.S. home-building firms had fewer than four employees. At the turn of the past century, there were, however, some large firms in the industry. While only 1 percent of firms had more than 20 employees in 1997, these larger firms accounted for 32 percent of annual receipts.

\subsubsection{Water-Heater Manufacture and Supply}

The residential water heater market is dominated by a small number of manufacturers, all of whom sell both residential- and commercial-sized storage water heaters, including electric-resistance immersion, and natural-gas- and propane-fired models. The Gas Appliance Manufacturer's Association (GAMA) lists annual sales of more than 4.9 million gas-fired heaters (4.6 million natural gas-fired) and 4.3 million residential electric water heaters in 2001, with the U.S. market growing gradually from 4.2 million gas-fired and 3.8 million electric units shipped from manufacturers in 1992 (GAMA 2003). The five largest manufacturers of residential models are Rheem Manufacturing, American Water Heater Company, A. O. Smith, Bradford White, and State Industries; all make both gas-fired and electric models (Cooper et al. 1997, PNNL 1995). The most frequently used gas-fired water heater is a tank-based 40-gallon model. Electric water heaters are most often of the 50-gallon tank-based type.

Other types of water heaters on the market include oil-fired and solar-powered appliances as well as desuperheater, geothermal heating and cooling systems, and multi-function water heating systems. Demand or tankless water heaters, also called instantaneous or booster heaters, are also sold in both gas-fired and electric models, notably to residences with limited space like apartments or mobile homes (Cooper et al. 1997, Focus Marketing Services 1999). Hybrid systems may combine two different water-heating technologies. Multi-function heating systems include hydronic systems that use tubing to pass heated liquids to locations around the home. The GAMA April 2003 Consumers Directory lists 20 brand-name residential water heaters, covering natural gas and propane-fired models, electric and oil-fired water heaters, heat-pump water heaters, and combination water heaters and space heaters.

\subsubsection{Linking Demand to Supply: Wholesale and Retail Distribution}

Supply Chain Memberships. Water heaters are produced at a relatively small number of manufacturing sites.

Rheem, headquartered in New York, has manufacturing facilities in Montgomery, Alabama; Fort Smith, Arkansas; Milledgeville, Georgia; and Oxnard, California.

American Water Heater Company's warehouse, with more than 1,000 employees, is located in Johnson City, Tennessee. GSW, Inc., of Oakville, Ontario, purchased American Water Heater Company in 2002.

A.O. Smith Co., as part of the ongoing integration of its State Industries acquisition, recently announced plans to consolidate the North American manufacture of residential water heaters at its Ashland City, Tennessee, and Juarez, Mexico, facilities. A. O. Smith Corporation also has facilities in Canada, England, Ireland, Hungary, the Netherlands, and China and employs approximately 17,000 people. 
State Industries, Inc. manufactures water heaters in Ashland City, Tennessee; water system tanks and expansion tanks in Charlotte, North Carolina; and parts for water heaters and tanks in Franklin and Cookeville in Tennessee.

Bradford White Corporation manufactures water heaters in Middleville, Michigan.

Each of these manufacturers has a number of parts suppliers to deal with. However, of more interest to the current project effort is the relationship between these manufacturers and their immediate customers.

The two major distribution channels for manufacturers of water heaters are plumbing wholesalers (such as Ferguson, Noland, and Apex) and large retailers (such as Home Depot, Lowes, Menards, and Sears) with total manufacturers' sales divided approximately equally between wholesale and retail buyers (although some manufacturers prefer to deal only with wholesalers). Plumbing firms and other contractors who install water heaters get their units primarily from these two sources, as do homebuilders who do not go through a contractor. An NREL-sponsored survey of 84 larger builders (producing at least 100 homes annually in southern California, Phoenix, Las Vegas, and Florida) (GAMA 2003) found that 82\% purchased conventional water heaters from the installing contractor/ subcontractor. Only 6\% purchased units directly from the manufacturer, and only $7 \%$ were purchased from a wholesale distributor (and $2 \%$ from "other"). Some $84 \%$ of the 31 distributors and subcontractors interviewed purchased their water heater units directly from the manufacturer (GAMA 2003 ), selling $77 \%$ of the time to a builder, $38 \%$ of the time to an other contractor or hybrid distributor/installer, $6 \%$ of the time to a retailer, and $16 \%$ of the time to "other" customers including wholesalers and homeowners.

Trucking seems to be the only mode of transport used throughout the supply chain. From the manufacturing sites or their regional warehouses, water heater units are shipped to a much larger number of retail and wholesale outlets. This appears to occur via a set of regionally located warehouse/distribution centers operated (or leased) by a manufacturer. The number of these warehousing sites could be obtained from each manufacturer (see below for some information from Rheem). From these distribution centers the manufacturer delivers units to a much larger number of local or regionally located retailers and plumbing contractors, as well as to some builders. The number of wholesale plumbing establishments was not readily available. As an example, the Apex Supply Company sells water heaters made by a number of manufacturers out of 23 locations around the southeastern United States, with headquarters in Atlanta, Georgia. The geographic coverage of the larger retail companies, such as Home Depot, Lowes, and Sears, is clearly more extensive.

Some utilities, including a number of regional energy-supply cooperatives, also sell specific energyefficient units to homeowners and/or plumbing contractors/water-heater installers. These sales are often subsidized, providing additional profit to the installer and (through agreement with the installer) to the homeowner. How and/or where these utilities obtain their supply of water heaters was unclear. One utility indicated that it helped homeowners find installers. Direct purchases from and delivery by the manufacturer might be one way to cut down supply-chain costs. How utilities acquire water heaters was also unclear. It also appears that these plumbing wholesalers/distributors are responsible for delivering their water heaters to the building sites or contractor locations by truck. A large builder might order a truckload of units for delivery to a building site. However, this implies that numerous units can easily be stored by the builder or are all being put into houses in short order. A more common situation could be for one or more units to be delivered to a specific location, implying lessthan-truckload transport. One would expect storage of water heaters to be pushed back up the supply chain to the extent possible, i.e., just-in-time delivery may now be the norm, as in some other manufacturing supply chains.

Supply Chain Processes. Key processes in supply chains include informational and financial as well as physical interactions or transfers between participants. In NREL's study of the market for solar 
water heaters, it was found that direct, personal selling to builders by installation contractors was the major and most successful (59\%) method of communication, with trade shows second, followed by trade advertising (NREL 1999). Manufacturer-based model homes programs, design centers, incentives, or discounts were also popular promotions with builders. Builders in turn referenced presentations by new-home-sales agents, manufacturers' brochures, and model-home point-ofpurchase displays as their top three methods of marketing to homebuyers. This same study (NREL 1999) also quotes a 1998 survey of 600 large builders (builders with annual sales of more than 100 units). Eighty-three percent of these builders used model homes to sell to homeowners in their communities. In choosing a specific energy-efficient product, builders in the NREL study cited their cost/profit, local code requirements, and level of consumer demand as their three main concerns. Two other 1998 surveys of builders are also cited in which supply-chain cost savings are seen as a key consideration.

Supply Chain Management and Integration. The profit margin on the manufacture of individual water-heater units is quite small (Cooper et al.), with heavy discounts on sales by retailers and wholesalers, who make up some of this through ancillary parts sales. The units must also be able to handle post-manufactured markups at each stage in the supply chain and notably at the point of installation. This means that new products seeking to enter the market must compete with a wellestablished and highly competitive industry that has been working to keep down its logistical costs. According to Cooper et al., "selling, general and administrative costs (including indirect labor, promotion, commissions, and transportation) in the appliance industry (not the water heater industry per se) are around $16 \%$, compared to about $6 \%$ profit. Any new products entering this market must be able to handle these sorts of numbers.

One way to reduce costs would be to better manage, and where possible, integrate, the supply chain. A form of supply-chain integration seems to be taking place in the case of Apex Supply Company, a wholesale distributor of plumbing and other supplies and a Home Depot company. Both Home Depot and Lowes will deliver and install water heaters in homes.

Some vertical integration of Rheem's supply chain is evident with the establishment of a nationwide network of warehouses to meet demands for quick delivery. Rheem uses seven USCO Logistics facilities across the United States. Rather than stock every model unit, USCO facilities store just several basic model types that can be customized at the warehouse. USCO can custom-configure each electric water heater by changing heating elements and the voltage and wattage to conform to the specific unit ordered. After configuring the product, USCO then labels water heaters with the appropriate model and serial number information based on the customer order. This mass customization strategy has apparently reduced Rheem's inventory carrying costs by $10 \%$. USCO Logistics is a full-service provider of globally integrated logistics solutions supported by sophisticated information systems. Rheem also uses United Supply and Distributing Company's (Rheem Supply) three warehouses in Maryland and Virginia for distributing its water heaters.

In addition to the larger wholesale and retail enterprises that dominate the physical distribution chain, small-scale distributors represent about $5 \%$ of the water heater market, supplying to both wholesalers and retailers, as well as occasionally to builders and contractors (i.e., installers). Controlled Energy Corporation (CEC), for example, with more than 65 employees, is a Vermont-based company that distributes tankless water heaters. It has no direct-to-customer sales. CEC products are available through home centers, hardware groups, catalogs, Internet stores, and plumbing and heating distributors. Web-based sales of water heaters appear to have represented about $2 \%$ of the market in 1996 (Cooper et al.) but have grown in recent years.

Most water heaters in new homes appear to be selected by the builder or by the contractor who installs the appliance. Architects involved in customized new home construction may also be responsible for model selection. Homeowners seeking replacement units might make the purchase decision, or might leave it to the installation contractor. 


\section{MARKET ADOPTION OF HPWH}

Besides the usual "chicken-and-egg" problems with getting a new product into an existing and wellestablished market, the following barriers and opportunities were identified via a literature search. A new product here is taken to be a residential energy-efficient water-heating system, such as the HPWH, including the “drop-in” type developed by ORNL and it industrial partners (Appendix B).

\subsection{SOME BARRIERS TO ADOPTION}

Innovation in the homebuilding industry appears to be difficult to promote because the industry is highly fragmented geographically, horizontally (i.e., limited interaction between firms within a region), and vertically (i.e., limited interaction and feedback among a product manufacturer, the builder, subcontractors, and the final customer). High turnover in the workforce may encourage the transmission of new ideas. However, as a process-based operation that is largely open and transparent to a large number of general and trade-based contractors, builders, and others in the industry find it difficult to protect their innovations. A cyclical business pattern that hinders employee retention also dampens the industry's (or builder's or contractor's) desire to train employees in new methods and products. Large homebuilding firms, many of them publicly held companies, have also shown themselves somewhat averse to risk when it comes to adopting innovative products, including installing new types of heating and cooling appliances (Baxter and Linkous 2002).

ORNL held a conference call with the ECR Sales Team on July 23, 2003 (Sales Director, West Coast Regional Sales Manager, Southeast Regional Sales Manager). The following observations were gleaned from this discussion:

- Marketing approaches with builders in new subdivisions are effective.

- Cost, consumer awareness, and contractor's technology perceptions are main barriers to market acceptance of HPWH technology. Product needs more promotion, and 7-year warranty needs to be more heavily publicized.

- Freight cost and warehouse costs are sales issues. Distributors don't want to stock the product until the market is developed.

- Consumers (generally described as consumers with higher than average income, education and environmental awareness) are searching the technology out themselves via the Internet.

- There are marketing opportunities where electricity prices are high.

\subsection{MARKET OPPORTUNITIES}

Possible opportunities for increased market penetration do exist. Based on the above discussion of barriers, there may be opportunities to improve market penetration of energy-efficient technologies such as HPWHs through

- a shortening of current supply chains dealing with new home starts by linking both utilities and builders directly to manufacturers, and

- by targeting new utility-based promotions at different actors involved in the water-heaterreplacement supply chains, i.e., the plumbing contractors/installers.

It is useful here to study the results of NREL's examination of the solar water heater industry and its potential for growth in the new homes market (GAMA 2003, Ghent and Keller 1999). While solar technology differs from HPWH technology in many ways and is primarily focused on new home installations, the following parallels may be worth considering: 
- Closer, more direct interactions between builders and manufacturers might encourage a greater understanding of products and their costs and benefits. (While the building industry is rather atomistic, some 100 of the largest builders apparently capture about $20 \%$ of the housing starts nationwide. If so, these companies may be a good target for future manufacturer-based product promotions).

- Price, brand name, and warranty were all found to be important to builders, as was on-time delivery in tune with a building schedule. The supply chain matters here.

- The introduction of energy-efficient water heaters as part of an energy-efficient package offered as a standard feature of the builder's new homes within a community.

\subsection{FUTURE RESEARCH}

The above discussion is based on a brief review of the literature available at the time. More data and in-depth knowledge is needed on both the relative size and nature of the interactions between those contractors or subcontractors installing water heaters, the homebuilders they serve, and the vendors (including any utilities) from whom they acquire the water heaters. How local utilities, including regional cooperatives, not only promote and subsidize, but also acquire and subsequently supply water heaters to final customers is also worth further study. These questions, in particular, need to be answered in more detail:

- What options are available and what barriers exist for regional utilities to acquire water heaters directly from manufacturers?

- What are the various mechanisms used by/available to utilities and/or state energy offices for encouraging both contractors and customers to select energy-efficient water heaters?

- How should utilities target their promotions?

\section{RESIDENTIAL MARKET}

\subsection{BARRIERS}

It is well established that HPWHs work from a functional perspective. While HPWHs are successful from the efficiency perspective, they haven't exactly taken the water heater market by storm. If HPWHs are so efficient, why aren't more of them being purchased? Researchers at Arthur D. Little addressed this essential question for DOE (Barbour et al. 1996). They concluded that high front-end costs, spotty reliability of early models, complicated installation procedures, and inadequate consumer knowledge combined to keep HPWHs from being successful in the marketplace.

HPWHs have failed to penetrate the residential electric water heater market for both technical and economic reasons.

An initial high first cost led to longer payback periods. Typical first cost for early HPWH models was $\$ 1,400+$ for a complete installation versus $\$ 400-\$ 450$ for an electric water heater. Depending upon installation conditions, payback periods for the incremental cost can be as little as two years (CEE 2002).

- Lack of confidence with the product

- Lack of familiarity with the product

- Limited availability and selection of products 
- Specialized installation: Because of the non-integrated design (heat-pump unit separate from tank) the components needed to be field-installed separately. This leads to a two-trade installation-an electrician for the electrical connections and a plumber for the water connections.

- Possibility of specialized service: In addition to specialized installation there is often the need for customized service.

- Misconceptions about reliability.

- The large amount of cooling produced by the evaporator added significantly to the heating load, so installations in the conditioned space were avoided in regions dominated by heating load hours. This eliminates a large portion of the potential HPWH market, particularly in areas where the electric rates are high

- $\quad$ Noise of units

- Large amounts of condensate were produced that had to be piped away from the water heater to a drain - another barrier to a simple installation. If no drain was available, a condensate pump was required, adding to the cost.

- Confusion about the purpose of product—some people think this is a space-conditioning heat pump.

- HPWHs work in locations where the temperature ranges from $40-90^{\circ} \mathrm{F}$ year-round.

Many of these barriers have been addressed. The new units are nearly drop-in replacement, much quieter, and more reliable.

\subsection{RECENT FINDINGS: RESIDENTIAL CONSUMERS AND THE HPWH}

\subsubsection{NYSERDA}

On April 15, 2004, NYSERDA's current market-based HPWH program will expire. NYSERDA will reevaluate the program while continuing to work with ECR on the energy-efficient HPWH.

NYSERDA has surveyed three homeowners who recently purchased the HPWH in New York and found that two of the three were reasonably satisfied although two of the three had control boards that failed.

\subsubsection{California Energy Commission}

Under Contract No. 500-98-028 for the California Energy Commission (Energy Commission) Public Interest Energy Research (PIER) program, TIAX LLC, Cambridge, MA, and Enviromaster International, LLC, Rome, NY (EMI) are conducting a project to refine the design of and demonstrate a "market-optimized" residential HPWH (California Energy Commission, "Design Refinement and Demonstration of a Market-Optimized Residential Heat Pump Water Heater" Final Report, April 2004, http://www.energy.ca.gov/pier/reports/500-04-018.html). TIAX (formerly the Technology \& Innovation Business of Arthur D. Little, Inc.) is the prime contractor, and EMI (a subsidiary of ECR International) is a key subcontractor and the manufacturer of the "market-optimized" HPWH, the Watter\$aver ${ }^{\mathrm{TM}}$. Under the scope of the project, TIAX and EMI have conducted a yearlong field test in California of 20 market-optimized HPWH prototypes. Eighteen of the units were installed in residences; one was installed at a commercial office building and another at a marina. The following text discusses the survey and summarizes test results.

"The results of the field test show that the prototype HPWHs effected average energy savings generally between 30 and 50 percent in residential applications (relative to the energy consumption of electric resistance water heaters as determined by simulation). There is no evidence that tight 
enclosures significantly impacted performance, based on the performance of the four units that were installed in tight enclosures. While the measured hot-water deficits (hot-water run-outs) ranged from 0 to 6.6 percent for the residential units (compared to 0 to 0.3 percent for simulated electric-resistance water heaters), participants in general did not notice a greater incidence of hot-water deficits.

"The control system proved to be the weak link in reliability of the prototype units. During the course of the field test, we replaced six failed control boards. We experienced one failed thermistor, one failed thermostat, and one refrigerant leak of undetermined origin. We also experienced one failed upper heating element, although this failure was technically after the completion of the field test. While the failure rate experienced is higher than would be acceptable in the residential water-heater market, EMI has made design changes in its production Watter\$aver to address the deficiencies identified in the field test. However, the reliability of the current Watter\$aver design has not been demonstrated through a large-scale field test.

"Field-test participants were generally satisfied with the performance of their HPWHs. One area that may need further attention is noise reduction. In some installations, where the HPWH was near bedrooms and other frequently occupied areas, the noise level was sufficient to cause complaints.”

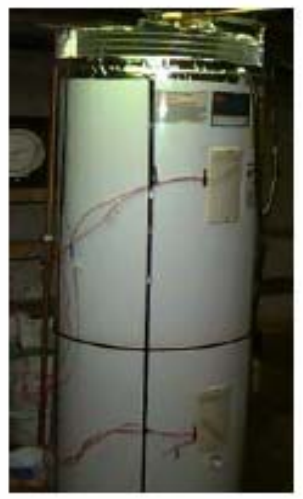

First-Generation HPWH Prototype

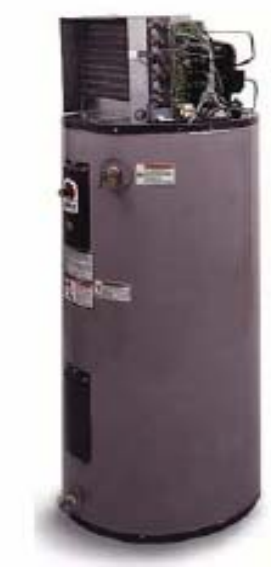

Second-Generation HPWH Prototype

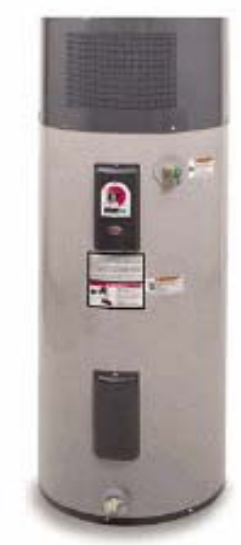

Third-Generation HPWH Prototype

Fig. 4. First-, second-, and third-generation HPWH prototypes.

\section{Summary of Participant Survey Results}

"Noise: The lowest average rating, 1.5, was in response to the noise from the compressor/fans of the HPWH. Participants were particularly sensitive to noise in sites where the installation was near frequently occupied areas (such as an office or guest bedroom). We anticipated that the noise category would yield unfavorable ratings compared to a silent electric-resistance water heater. The rating of 4 from one participant may have arisen from confusion in filling out the survey. The participant may have misinterpreted a rating of " $4=$ Somewhat better than previous water heater" to mean that the noise level of the HPWH is somewhat greater than the previous water heater.

Hot Water Deficits: Participants generally seemed satisfied with the hot-water delivery of their HPWHs, resulting in an average rating of 3.3 for the category. In the case of Unit 10, which used an average of 166 GPD, some comments indicated that there was less hot water available than with their previous water heater. The impression of the TIAX field engineer is that some participants subtly change their usage habits to accommodate the slower recovery time of the HPWH. Again, field-test volunteers may be more accepting than the general public of inconveniences associated with energy savings. 


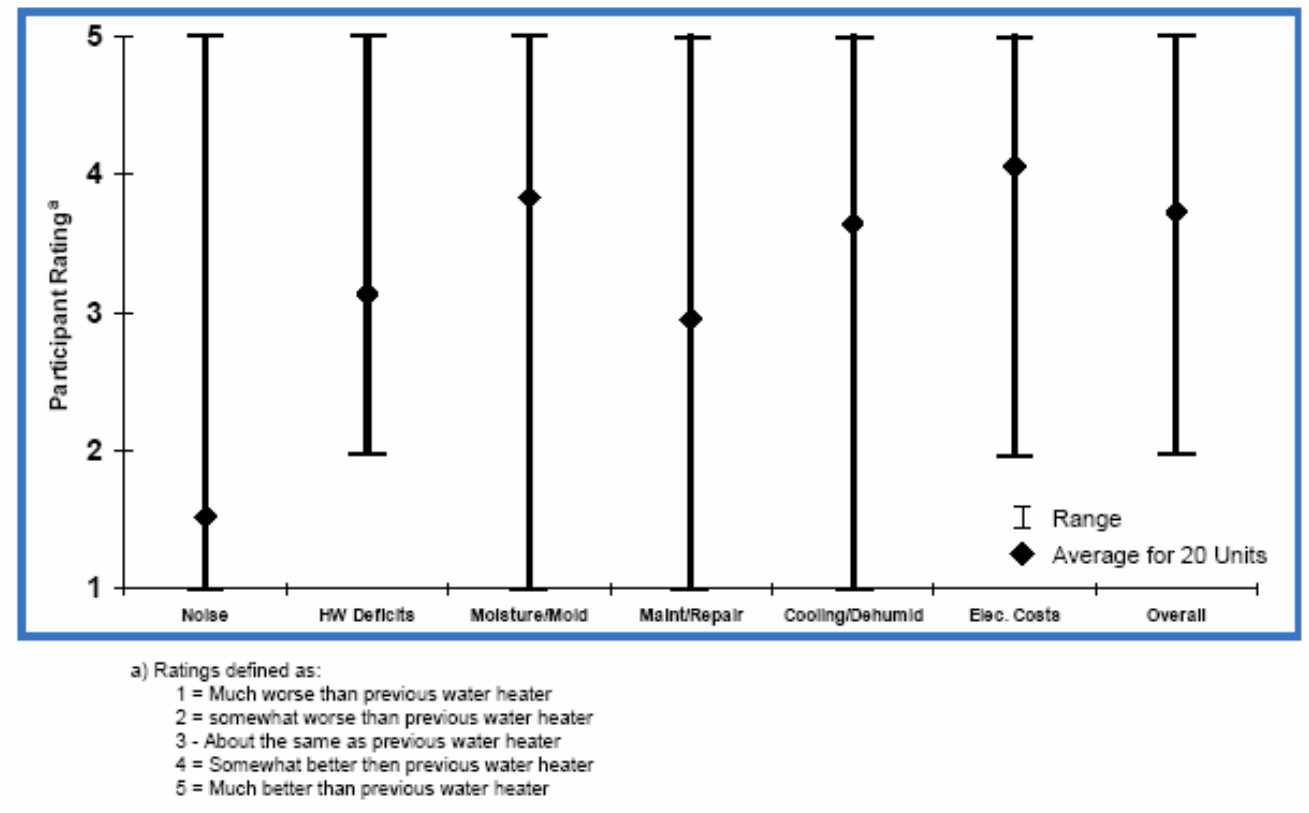

Fig. 5. California Energy Commission survey results.

Moisture/Mold/Mildew: Ratings ranged from 1 to 5, with an average rating of 3.4 Participants concentrated their comments (and most likely ratings) to the condensate line. The participants could observe the condensate (moisture) coming out of the HPWH and, in some cases, mold/mildew formed around the condensate drain connector. In one instance, the primary condensate line was plugged and the secondary condensate line was dripping along a wall that started forming mold/mildew.

Maintenance/Repair: We expected a rating of 3 or less because a conventional electric-resistance water heater rarely requires maintenance/repair/attention. Some HPWHs in the field test required attention/repair. Generally, participants gave ratings of 5 if they had no maintenance or operational problems, which skewed the average rating upward, to 3.0.

Cooling/Dehumidification: The HPWH evaporator removes moisture from its environment, so we expected a favorable rating. However, reaction to this category varied widely, from 1 to 5 . There were five installation locations where the operation of the HPWH impacted a conditioned space. The host reaction to this depended on the season. In the hot season, the added cooling provided by the HPWH was perceived as a benefit, while in the cold season, the addition of cool air to the room caused comfort problems for the occupants. In other parts of the country (for example, in New England, where basements are common), the dehumidification effect might be more highly valued The remaining fifteen sites were not effected by the cool evaporator air, as is reflected in the 3.7 rating for the category.

Electricity Savings: Participants were generally happy with the electricity/cost savings when they were able to notice a change in their utility bills. The overall average for the category was 4.0. The rating of 2 came from a participant who noticed their energy bill was higher than the previous year. However, the host also said that this may be due to the use of new space heaters." 


\subsubsection{Northeast Utilities}

Northeast Utilities in Hartford, CT (www.nu.com/) is conducting field tests of 18 ECR units. These tests will be completed in the fall of 2004.

\subsubsection{ORNL Focus Group Teleconference Findings}

ORNL held a telephone focus group on June 3, 2003, to examine the issues surrounding market adoption of HPWH technology.

The following organizations were represented:

- ORNL

- Austin Energy

- Consortium for Energy Efficiency (CEE)

- Bonneville Power Administration

- National Grid (includes Niagara Mohawk, Massachusetts Electric, Narragansett Electric, Granite State Electric, and Nantucket Electric)

- ACEEE

- PG\&E

- Oregon Energy Office

The participants made the following general observations:

- Sacramento Municipal Utility District (SMUD) did not feel ready to participate in the focus group until its current field test of 20 units was complete (field test is ongoing and only two units are currently in the market).

- Austin Energy is developing a \$100 incentive program for the HPWH

- Each utility is going to have its own perceptions of the technology

- A utility will not promote a product unless it is sold on it because of the need to maintain its reputation and trust with the end consumer

- Not sure if utilities will go to web site to fill out survey due to time constraints. Might be best to distribute survey via email.

- Participants summarized the following barriers:

- Technology too new to address load (possible answer: more field testing). Another potential strategy is to conduct a large-scale demonstration project similar in scope to the "Bern Clothes Washer Report.” See: http://www.eere.energy.gov /buildings/emergingtech/pdfs/bernrpt.pdf

- Reliability uncertainty (possible answer: extended warranties)

- Cost (possible answer: reduce cost, incentives, promote payback period)

- Attributes unknown (dehumidification, reduction in air emissions, saves power for commercial/industrial utility market segments)

- Uncertainty of installation and how to repair- who needs to be involved (HVAC contractor, electrician, plumber, homeowner) (possible answer: promote ease of installation and maintenance) 


\subsection{Promoting Market Growth}

"Education is not enough," says Smith, co-author of Fostering Sustainable Behavior: An Introduction to Community-Based Social Marketing (McKenzie-Mohr and Smith 1999). "Segmentation is important. You need to reach your target audience. If you have a good product and poor placement, it may not succeed."

There are commonly understood conditions for growth of a market or product (CEE Market Transformer News 2002):

- It's something people want,

- It's available at a price people want to pay,

- It's easily available, and

- It's seen as popular.

In general, existing information indicates that HPWHs are generally more cost-effective in warm climates, especially areas where electric costs are high and natural gas is also high or unavailable. As evidence of this, HPWHs have most successfully penetrated the U.S. residential and commercial markets in Hawaii.

HPWHs should also be considered in residences located in cool climates where there is also a need for mechanical ventilation. Some HPWHs are designed to recover heat from exhaust air from a mechanically ventilated residence. These types of HPWH provide effective heat recovery for these residences, and as a result of this, have become common in areas of northern Europe.

HPWHs are most cost-effective in buildings where hot-water energy use is relatively high and the greater savings in hot-water energy cost can offset the higher first cost of the HPWH over other water heating technologies (PNNL 1995).

Residential exhaust-air heat pumps vary widely in capacity from about 4,000 Btu/hr to 90,000 Btu/hr, and tank size ranges from 80 to 120 gallons. Contribution to air-conditioning equals about two-thirds of the water-heating capacity when operating as an ambient air-source unit. Ambient air-source units start at about $\$ 700$ for retrofits to existing water heaters, and exhaust air units cost $\$ 1,400$ or more. Paybacks are reported to range from 3 to 20 years, but are quickest in applications where cooling air can be used year-round (FEMP 2004).

\section{UTILITY MARKET}

\subsection{MARKETING ENERGY EFFICIENCY}

Electric utility companies, rather than the manufacturers, have done much of the promotion for HPWHs. Electric utilities have historically funded programs to encourage the development of a host of clean energy technologies. Some utilities offer specific incentives to promote adoption of HPWH systems. Many of these programs are called "market transformation." These incentives are an attempt to make it worthwhile for manufacturers to invest in new production lines and for distributors to stock products they would not ordinarily stock. In addition, the utilities' subsidies make consumers more likely to accept the efficient products.

"A survey of 2321 programs conducted by 666 electric utilities found that 18 utilities offered customer incentives ranging from $\$ 1200$ to $\$ 1500$ for commercial HPWH systems. With some utilities, the incentive amount is tied both to the power draw of the unit $(\mathrm{kW})$, and to the storage tank 
volume. Although many utilities do not offer incentives, they provide information to consumers and perform field studies of systems installed in their service territories.” (FEMP 2003)

The utilities most actively promoting HPWH technology include:

- Georgia Power Company-Incentive is $\$ 500 /$ ton with installation to have a 12-h minimum daily run time; provides installer training programs.

- Alabama Power Company-Incentive is $\$ 200 / \mathrm{kW}$ ( $\$ 300 / \mathrm{kW}$ for Healthcare) plus $\$ 2.50 /$ gallon for water storage tank up to 720 gallons and \$2.00/gallon for $720+$ gallons; provides training programs.

- New England Electric System-Full incremental cost reimbursement; mechanical/electrical system design services.

- Potomac Electric Power Company-Incentives of \$1000/unit for HWHP (min. COP = 2) with more than 50 gallons of storage.

- Hawaii Electric Company_-Promoting HPWH; Hawaii provides a state tax credit of $20 \%$ of system cost subject to a maximum depending on the application.

Other utilities with commercial HPWH programs include:

- Fort Payne Improvement Authority (Alabama)

- Arizona Public Service Company

- Florida Power Corporation

- Rochester Gas \& Electric Corporation, New York

- Four County Electric Power Association, Mississippi

- Ohio Edison Company

- Pennsylvania Electric Company

- South Carolina Electric \& Gas

- Chattanooga Electric Power Board, Tennessee

- Central Power \& Light Company, Texas

- Central Vermont Public Service

- Snohomish County PUD, Washington

- Madison Gas \& Electric, Wisconsin

- $\quad$ TU Electric, Dallas

- Wisconsin Electric Power Company

One gas utility promoting energy efficiency is KeySpan Energy Delivery New England. The company is promoting efficiency for water heaters among other initiatives. Massachusetts is the only part of KeySpan's customer area that has an energy-efficiency mandate.

\subsubsection{Problems with Utility Promotions}

One of the most difficult problems with utility-sponsored incentive programs is making multiple-year commitments. This is particularly important in new construction, where two or more years may pass 
between the design phase for a building - the phase when key energy-efficiency decisions are made by the architect - and the construction phase, after which inspections are needed to determine whether the proposed design was actually implemented. For the architect to commit to spend more money for energy-efficiency design in, say the year 2003, he/she has to know that the incentive will still be available even if the building isn’t finished until the year 2006. Given state utility budgeting proceedings, which are similar to the annual appropriations process in Congress, such assurances are difficult or impossible to provide. Tax credits may offer more stable incentives than the utilities for this reason. (U.S. Congress 2003)

\subsection{HPWH PROGRAMS AND INITIATIVES}

\subsubsection{NYSERDA}

The New York State Energy Research and Development Authority (NYSERDA) is a public benefit corporation created in 1975 by the New York State Legislature. NYSERDA, in cooperation with ECR International and the Hudson Mohawk Chapter of the Refrigeration Service Engineers Society (HMRSES), has been conducting a pilot program designed to promote the installation of energyefficient HPWHs. On April 15, 2004, NYSERDA's current market-based HPWH program will expire. NYSERDA will reevaluate the program while continuing to work with ECR on the energyefficient HPWH.

The primary objective of the program was to have customers install HPWHs when replacing old, inefficient electric water heaters. NYSERDA promotes HPWHs because they have a superior efficiency rating compared to even new electric units, potentially saving consumers up to $60 \%$ on their monthly water-heating bill. A second objective of the pilot program was to develop an infrastructure of contractors trained to properly install and service the HPWHs. (Air Conditioning, Heating \& Refrigeration News 2002.)

NYSERDA surveyed three homeowners who recently purchased the HPWH in New York and found that two of the three were reasonably satisfied although two of the three had control boards that failed.

\subsubsection{E Seal Initiative}

E Seal is the electric industry's nationwide residential energy-efficiency and environmental initiative, endorsed by the National Association of Home Builders and the U.S. Environmental Protection Agency.

Edison Electric Institute manages the E-Seal Initiative. Tom Farkas is the Residential Programs Manager for the Edison Electric Institute. E Seal business partners offer substantial benefits and incentives to E Seal utilities.

E Seal Water Heater Rental Programs from Vaughn Manufacturing. Vaughn, which manufactures only energy-efficient water heaters and distributes them directly through electric utilities, now offers E Seal utilities a turnkey rental program. Utilities can buy or lease the water heaters from Vaughn, then rent them to customers for a low monthly fee that includes all maintenance.

\subsubsection{Energy Star Program}

EPA and DOE tried to establish an Energy Star standard for water heating. The late appearance of an Energy Star specification for water heaters is more institutional than technological. For example, the manufacturers of HPWHs are different from those of resistance water heaters--the HPWH manufacturers are small companies. Energy Star prefers to deal with existing manufacturers and associations with a national sales network; by effectively endorsing HPWHs, Energy Star would alienate the existing manufacturers and possibly promote an infant industry not capable of quickly 
expanding to meet increased demand. A HPWH may also have a lower life-cycle cost than a naturalgas-fired water heater. Thus, Energy Star would potentially encourage fuel switching, an act that would raise the ire of gas utilities. Any one of these institutions could have stopped an Energy Star program.

Bigger manufacturers like Whirlpool and Carrier may be waiting and won't move until Energy Star enacts a program for water heaters. A fundamental issue was whether to introduce one Energy Star standard for all electric water heaters, or to create separate resistance and heat pump standards. If Energy Star should establish a separate specification for resistance water heaters, it would impede the transition to HPWHs (Home Energy 2002).

To gain the interest and financial commitments of utilities, the incremental savings offered by the Energy Star label compared to the base case must be significant. If Energy Star establishes a weak specification for water heaters, there is a high probability that utilities will choose: a) not to offer incentives, or b) to establish their own specifications at levels higher than Energy Star. As was seen for many Energy Star products, when DOE or EPA sets an appropriately strong specification the utilities will rally around it and often offer significant incentives. The net result is much greater energy savings and increased market share for the more efficient models (Natural Resources Defense Council 2003).

A new federal water heater standard was set to go into effect on January 20, 2004. However after analyzing the market, the potential energy savings and economics of the various technologies, and considering feedback from stakeholders, the Department of Energy has decided not to establish Energy Star criteria for domestic water heaters at this time. A January 6, 2004 letter (available at: http://www.energystar.gov/index.cfm?c=new_specs.water_heaters) from Richard Karney, the Department's Energy Star Program Manager explains the rationale for this decision, with primary points summarized as follows. The letter can be read in its entirety at the website.

- Labeling "non-conventional” products would not insure product performance could be maintained or enhanced with ENERGY STAR compliant products compared to non-compliant models.

- For most "non-conventional" technologies, purchasers would not recover their incremental investment within a reasonable time period.

- Product availability and infrastructure for "non-conventional” products is not yet broad based.

Karney writes that Energy Star labeling for HPWHs should not be ruled out: “... heat pump, gas condensing, solar and tankless gas water heaters are promising technologies that might warrant inclusion in the Energy Star program at some point in the future. Each of these products has significant energy savings potential compared to conventional products. This is true even at relatively modest market penetrations. If these products eventually achieve widespread market acceptance, tremendous gains in energy savings and associated pollution prevention could be achieved...”

\section{SUMMARY AND CONCLUSIONS}

The HPWH has been on the residential market for twenty years. There are three U.S. manufacturers selling two different types of product on the market. ECR International is selling a stand-alone "dropin" HPWH that can be purchased to replace an existing water heater. Nyle Corp. and Applied Energy Recovery Systems produce and sell "add-on” HPWHs that connect to existing water heaters to save energy and provide dehumidification. The two primary barriers to market penetration found in this analysis are price (as compared to or in addition to a standard water heater) and performance. 
Many early products were deployed before proper field testing. Although ECR and Nyle have improved their products, some utilities have negative preconceptions of the product. In California, the ECR unit is undergoing additional field-testing; Nyle units are being tested at ORNL in Tennessee.

Until a significant market has developed for the HPWHs, their price cannot be significantly lowered. Furthermore, the product will not be picked up by large "do-it-yourself" stores, it will not receive "Energy Star" labeling, and it will not be widely marketed.

Outside the utility channels, only a few hundred HPWHs have been sold nationwide, mostly from sales managers marketing to builders in new subdivisions and homeowners researching the Internet for energy-efficient water heaters. Each company sells the product via their own distribution channels using existing sales representatives whose main business is other products. The HPWHs are not heavily marketed and are not well stocked in distribution centers. Therefore, they are made to order and usually transported by truck on demand.

ECR has been working closely with NYSERDA to promote the HPWH in New York through incentive programs and informational training workshops for contractors. However, even with the incentive, an HPWH costs more than a standard water heater.

ECR is also reviewing the European and Asian markets for the HPWH. There are European HPWH products on the market, and ECR does have a distribution system overseas. However, the power line frequency of the compressor needs to be modified from 60 cycles to 50 for the ECR "drop-in" to work in these markets.

We reached several conclusions through our survey of New York and other targeted utilities (see Sect. 1, Introduction), among them that consumer interest is a decision factor in the adoption of HPWH for most of the smaller New York utilities and the consortia that represent them. (No nonNew York utilities identified consumer interest as a decision factor.) Lowering peak demand was mentioned by $28 \%$ of the respondents, among them the smaller New York utilities, utility consortia, and non-New York utilities. The large non-New York utilities all mentioned their or their regulatory agency's requirement that the technology meet one or more “tests” of appropriateness. Respondents discussed increased profitability, an important factor, in two contexts. First, utilities can increase their sales by entering markets previously held or dominated by nonelectric service. Second, two utilities mentioned improving revenue by improving its load factor in winter.

A technology's ability to lower utility bills was the attribute utility customers identified with greatest frequency. Product familiarity and reliability are more important than other attributes, including energy savings, which two respondents specifically noted was not valued by their customers.

Nearly half of the respondents said they did not promote energy-efficient technologies. All but one of these respondents was a New York utility. Respondents explained that NYSERDA assumed the responsibility for DSM and energy-efficiency promotion.

Several utilities have expressed interest in promoting the HPWH. In addition, in its Fall 2003 Newsletter, the Consortium for Energy Efficiency announced the formation of a Heat Pump Water Heater Exploratory Committee to provide a forum to discuss the product's opportunities and market barriers and to consider the benefits of coordinated action.

The first step toward market transformation is to address the HPWH's performance reliability. Next, the manufacturers could engage select utilities to aggressively market the HPWH. A tiered approach could target distinct segments of the market with the potential for the highest benefits from the technology. Communications media that address performance issues should be developed. When marketing to new home builders, the HPWH could be introduced as part of an energy-efficient package offered as a standard feature by builders of new homes within a community. 
Conducting focus groups across the United States to gather input on HPWH consumer values will feed input back to the manufacturers. "Renaming" and "repackaging" the HPWH to improve consumer perception, appliance aesthetics, and name recognition, should be considered. Once an increased sales volume is achieved, the manufacturers should reinvest in R\&D to lower the price of the units. The manufacturers should work with "do-it-yourself" stores to facilitate introduction of the technology to these sales venues.

The HPWH is an excellent example of a technology that would have benefited from the implementation of a market research program run in parallel with the technology R\&D program. Understanding consumer values and "willingness to pay" for product attributes and recognizing the corresponding influences those values have on purchase decisions are crucial. This knowledge should be incorporated into the $R \& D$ process with continuous between the market research and the $R \& D$ programs. Partnerships among stakeholders to gather consumer feedback and market analysis during R\&D will facilitate a strong framework for successful market penetration of energy-efficient technologies.

In summary, our market analysis revealed that although the HPWH is a developed energy-efficient technology, it has market barriers that if addressed, could facilitate market-adoption. Understanding and addressing consumer values in partnership with utilities and other stakeholders are key needs for success.

\section{REFERENCES}

Air Conditioning, Heating \& Refrigeration News, “Saving on Water Heating Bills," Sept 30, 2002 v217 i5 p7(1).

Barbour, C. E., Dieckmann, J. T., and Nowicki, B .J. Market Disposition of High-Efficiency Water Heating Equipment. Report prepared by Arthur D. Little, Inc. for the U.S. Department of Commerce, Report PB97145379. November 1996.

Baxter, V. D. and Linkous, R. L., May 2002. Durability Testing of a Drop-In Heat Pump Water Heater. ORNL/TM-2002/92.

California Energy Commission, "Design Refinement and Demonstration of a Market-Optimized Residential Heat Pump Water Heater” Final Report, April 2004, Prepared by TIAX LLC. http://www.energy.ca.gov/pier/reports/500-04-018.html

CEE (Consortium for Energy Efficiency, Inc.) 2002. Market Transformer News, Spring 2002. "Heat Pump Water Heater Passes Another Test.”

CEE Newsletter ,Fall 2003. “CEE members renew interest in heat pump water heaters.” http://www.ceeformt.org/resrc/news/03-10nl/21_hpwh.html

Center for Housing Research, Virginia Polytechnic Institute and State University, The Diffusion of Innovation in the Residential Building Industry, April 2003.

Chili Pepper Appliance Home Improvement website, 2004.

(http://www.chilipepperapp.com/hpwh.htm).

Cooper, M. C., Lambert, D. M., and Pagh, J. D. "Supply Chain Management: More Than a New Name for Logistics.” International Journal of Logistics Management, 8: 1-13, 1997. 
Doctor, Titu R., Johnson, Russell K., and Stone, Robert. "Issues troubling the market for residential heat pump water heaters in the USA and some possible solutions,” IEA Heat Pump Center Newsletter, Volume 21 - No. 4/2003.

ECR International (http://www.dunkirk.com/products_wattersaver.asp)

Energy Conservation News Nov. 2001. “OUTLOOK: Incentives Have Efficiency Benefits.” Vol. 24, Issue 4.

ET Currents, “Whatever Happened to Residential Heat Pump Water Heaters,” E-Source Emerging Technology Service, Number 27, June 2003.

FEMP (Federal Energy Management Program). Federal Technology Profiles. http://www.energy.wsu.edu/cfdocs/tg/21.htm)

FEMP Federal Technology Alerts: Commercial heat-pump water heaters, (http://www.pnl.gov/fta/3 res.htm).

Focus Marketing Services. Creating a Comprehensive Solar Water Heating Deployment Strategy. NREL/SR-550-26842. National Renewable Energy Laboratory, Golden, CO. 80401-3393. July 1999.

GAMA (Gas Appliance Manufacturers Association). Consumers’ Directory of Certified Efficiency Ratings for Heating and Water Heating Equipment. April 2003.

Ghent, P. and Keller, C., Marketing and Distribution Solar Water Heaters in the New Home Industry. NREL/SR-550-27122. National Renewable Energy Laboratory, Golden, CO 804013393, November 1999.

Hassell, S., et al., Building Better Homes: Government Strategies for Promoting Innovation in Housing. Report prepared for the U.S. Department of Housing and Urban Development. MR1658, RAND, Santa Monica, CA 90407-5050, 2003.

Home Energy 2002. “The next Energy Star product” (Editorial), Alan Meier, v19 i6 p2(1), November-December.

IEI (The Institute for Energy Information). www.ieionline.org/residential/ appliances/hotwater.htm)

"In Hot Water...A Newsletter about Heat Pump Water Heaters and Efficient Domestic Water Heating,” December 2002, March 2003, June 2003.

Iowa Energy Center website: http://www.energy.iastate.edu/efficiency/residential/ homeseries/waterheaters/types.htm.

Knight Ridder/Tribune News Service 2003. “Consider solar-water-heating system for your home,” April 3, page K1364.

Lambert, D. M. “The Supply Chain Management and Logistics Controversy.” Chapter 7 in "Handbook of Logistics and Supply-Chain Management” (A. M. Brewer, K. J. Button, and D. A. Hensher, Eds.). Pergamon, 2001.

McKenzie-Mohr, D. and Smith, W. Fostering Sustainable Behavior: An Introduction to CommunityBased Social Marketing, New Society Publications, 1999.

Mechanical Engineering-CIME March 2003. “Taking the Long View: Engineers are Studying Methods for Controlling the World’s Ever-Growing Appetite for Energy,” V125 i3 pD22(3).

Natural Resources Defense Council May 2003. Memorandum.

NREL 1999. Creating Comprehensive Solar Water Heating Deployment Strategy. NREL/SR-55026842. National Renewable Energy Laboratory, Golden, CO. 80401-3393. July. 
NYSERDA 2002. Pilot Program Can Save Consumers up to 60\% on their Water-Heating Bills, September 12.

ORNL (Oak Ridge National Laboratory) 2002. Field Testing of a "Drop-In" Residential Heat-pump Water Heater, Murphy, R.W., and J. J. Tomlinson, ORNL/TM-2002/207, September.

ORNL 1999. Bern Clothes Washer Study Final Report, Tomlinson, J. J. ORNL/M-6382, January 1999.

PNNL (Pacific Northwest National Laboratory) 1995. Federal Technology Alerts, http://www.pnl.gov/fta/3_res.htm.

PR Newswire 2002. “Alliance to Save Energy Urges Senate to Adopt Finance Committee’s Energy Efficiency Incentives,” February 15.

Rheem Manufacturing 2003. (www.rheem.com.au/images/pdf/owners_heatpump_126511B_0212.pdf)

Sachs, H., Toward Market Transformation: Commercial Heat Pump Water Heater for the New York Energy Smart ${ }^{S M}$ Region. Report prepared for the New York State Energy Research and Development Authority. Agreement 6299. American Council for an Energy-Efficiency Economy, October 2002.

U.S. Congress 2003. S507-HR1271, "Background and Summary, Tax Incentives for Energy-Efficient Buildings Legislation,” Senators Olympia Snowe (R-ME) and Dianne Feinstein (D-CA), Representatives Randy ("Duke”) Cunningham (R-CA) and Ed Markey (DMA), S. 507/H.R. 1271, Updated as of 14 March 2003.

U.S. Department of Energy (DOE)-EERE 2003. 2003 Buildings Energy Databook, Washington, DC, August 2003 (http://buildingsdatabook.eere.energy.gov/).

U.S. Department of Energy, Energy Information Administration, 2001 Residential Energy Consumption Survey, http://www.eia.doe.gov/emeu/consumption

Zogg, Robert A., et al.: Market Optimized Heat Pump Water Heater - Phase I; Final Report; prepared for Oak Ridge National Laboratory under Lockheed Martin Subcontract No. 62XSX974V; prepared by Arthur D. Little, Inc. (ADL Reference 35390-00); November 20, 1998. 
ORNL/TM-2004/81

INTERNAL DISTRIBUTION

1. B. G. Ashdown

2. E. Baskin

3. V. D. Baxter

4. G. D. Boudreau

5. M. A. Brown

6. J. E. Christian

7. W. Craddick

8. R. Linkous

9. P. M. Love

10. V. C. Mei
11. S. Schexnayder

12. M. J. Sherrod

13. F. Southworth

14. J. J. Tomlinson

15. M. Voss-Lapsa

16. Central Research Library

17-18.

17.

18.

\section{EXTERNAL DISTRIBUTION}

19. J. Dion, U. S. Department of Energy, 5E-042, Forrestal Bldg., 1000 Independence Ave. SW Washington, DC 20585

20. J.A. Laitner, U.S. Environmental Protection Agency, 501 3rd Street NW, 4th Floor, Washington, DC 20001

21. M.J. McCabe, U. S. Department of Energy, Forrestal Bldg., 1000 Independence Ave. SW Washington, DC 20585.

22. J.E. Rannels, U. S. Department of Energy, EE-2J, Forrestal Bldg., 1000 Independence Ave. SW Washington, DC 20585

23. J. R. Brodrick, PhD., 1J-018, EE-2J, 1000 Independence Ave. SW ,Washington, DC 20585

24. R.L. Orrison, U. S. Department of Energy, EE-2J, Forrestal Bldg., 1000 Independence Ave. SW Washington, DC 20585

25. 


\section{APPENDIX A. UTILITY SURVEY}

To understand utilities' decision criteria and marketing experience regarding energy-efficient technologies, researchers at the University of Tennessee in Knoxville implemented a survey of utility employees responsible for marketing and managing energy-efficient technology to residential customers. The information was sought to help define appropriate market-adoption strategies for energy-efficient technologies, like the HPWH.

ORNL researchers compiled a list of all New York utilities. With information available at these utility websites or acquired through telephone calls to them, we identified the utility representative most closely associated with marketing energy-efficient technologies to residential customers. Through this method, 56 individuals representing New York utilities were included in the sample. The same was done for a select group of non-New York utilities, with a focus on market areas dissimilar to New York, adding another 12 individuals to the sample. Two representatives of a consortium of New York utilities were also included.

The research team developed and pilot-tested the survey instrument, which was then administered by email or by facsimile to the sample. Approximately two-thirds of the sample received the survey by email; the remainder, who were not accessible by email, received it by facsimile. Reminders were sent seven business days after the survey was initially delivered. Another five business days later, phone calls were placed to each New York utility representative on the sample. Messages were left with roughly 75\% of the survey sample; another 15\% could not be reached. Researchers talked directly with 5\% of the sample, and completed the survey by phone with one individual. The response rate was $21 \%$.

The survey sought information about how utilities decide to promote technologies, customer values, the utilities' practices for promoting energy-efficient technologies, current interest in those technologies, and experience with HPWHs and interest in their promotion. The questions were open-ended, but many included prompts. The survey is included in Appendix A.

Data were recorded in an Excel spreadsheet. Although the questions were open-ended, the number of discrete responses was not extensive, so minimal aggregation of the data was required. The data are presented here in the charts and graphs that follow.

Because the survey sample emphasized New York utilities, they account for 53 percent of respondents. However, proportional to the sample size, the response rate from utilities outside New York, at 42 percent, was much better than the rate of response from New York utilities. The survey follows. 
Dear Mr./Ms [add name here],

Are you responsible for managing or marketing technology to [add utility's name here] residential electric customers? If so, would you please take about five minutes of your time to answer the questions below and share your insight and first-hand experience in promoting energy-efficient products to your residential customers. (If you're not the appropriate person at your organization to answer this, please forward to the right person.)

Oak Ridge National Laboratory (www.ornl.gov) and the Joint Institute for Energy and Environment (www.jiee.org) are conducting research to help define appropriate market adoption strategies for emerging technologies, such as the HPWH. The resulting report will be made available to you through the Web, but neither you nor your company will be identified in the text of the report.

We look forward to receiving your input via return email by close-of-business, Friday, September 5, 2003. Your response really is important to me. Simply reply to this email, type in your answers to the questions, and send the reply. Your reply will go directly to the researcher who will collect and analyze this information. If you have any questions, please contact me at 865-974-5912, schexnayder@utk.edu. Thanks, in advance!

\section{Susan M. Schexnayder}

1. What factors are most important to you when deciding to promote a new technology to your customers? (for example, proven results; providing energy savings opportunities for customers; costs close to the standard product; short payback periods; consumer interest; builder interest; contractor interest; management interest; lowering peak load; managing base load; score on a test such as ratepayerimpact, societal, or total-resource-cost test; minimal involvement required of utility staff; availability of reliable information about the technology; others...)

2. What do your residential customers value most about a technology? (for example, lower electric bills; energy savings; short payback periods; costs close to the standard product, advanced features; reliability; product warranty; proven results; easy do-it-yourself installation; use and maintenance similar to the standard product; convenient to buy; readily available information about the technology; others...)

3. What, if anything, do you do to promote new energy efficient technologies?

4. How do you get information that you use in your decisions to promote a technology?

(for example: publications (external to your company); Web sites (external to your company); conduct your own field tests/research; personal contacts; conference and trade shows; email; radio and television; others...)

5. What kind of new energy efficient technologies would you be interested in promoting to your residential customers? (for example, heat and air conditioning systems, HPWHs, weatherization products, lighting, kitchen/laundry appliances, not interested in promoting technologies; others...)

6. Are you familiar with heat-pump water heaters? If yes, please explain your experience with this technology.

7. Under what circumstance would you consider promoting heat-pump water heaters to your residential customers?

8. Would you be interested in participating in a free residential heat-pump water heater (or other emerging technology) field study or demonstration in your community?

9. Would you be interested in free marketing materials regarding residential heat-pump water heaters that you could use in your utility statements and on your utility web site?

10. Do you have any further comments on this topic?

11. Could we contact you if we have follow-up questions? 
Thank you for helping us to understand how new energy efficient technologies, especially heat-pump water heaters, can be promoted by electric utilities and their consortia. When the report summarizing this information is available, we will contact you with the web address where you can obtain it.

Susan M. Schexnayder

Energy, Environment and Resources Center

University of Tennessee

314 Conference Center Bldg

Knoxville, TN 37996-4138

865-974-5912

865-974-4609 (fax)

schexnayder@utk.edu

\section{SURVEY RESULTS}

- Consumer interest is a decision factor in the promotion of HPWH for most of the smaller New York utilities and the consortia that represent them, suggesting that they are more consumer-driven than the larger New York utilities and the non-New York utilities, none of which identified consumer interest as a decision factor.

- Lowering peak demand was mentioned as a factor by $27 \%$ of the respondents, among them the smaller New York utilities, utility consortia, and non-New York utilities.

- The large non-New York utilities all mentioned their or their regulatory agency's requirement that the technology meet one or more "tests" of appropriateness. These tests include the total resource cost, participant, and societal tests.

- Increased profitability was discussed in two contexts. First, utilities can increase their sales by entering non-regulated markets previously held or dominated by nonelectric service. Second, two utilities mentioned improving revenue by improving load factor in winter.

- A technology's ability to lower utility bills was the attribute most frequently cited by utility customers.

- Familiarity and reliability were more important than other attributes, including energy savings, which two respondents specifically noted was not valued by their customers.

- Nearly half of the respondents do not promote energy-efficient technologies. All but one of these "nonefficiency-promoting" respondents was a New York utility. Respondents explained that NYSERDA assumed the responsibility for DSM and energy-efficiency promotion. 


\section{APPENDIX B. ORNL HPWH FIELD TESTS}

The HPWH has been on the residential market for twenty years. Currently there are three U.S. manufacturers with two different types of HPWHs on the market. ECR International is selling a standalone, “drop in” HPWH (Watter\$aver) that can be purchased to replace an existing water heater. Nyle Corp. and Applied Energy Recovery Systems (E-Tech product line) produce and sell "add-on” HPWHs that connect to existing water heaters to save energy and provide dehumidification.

The integrated, “drop-in” HPWH unit was employed in the field tests described in Field Testing of a “Drop-In” Residential HPWH, (Murphy and Tomlinson 2002). Testing was conducted in selected laboratory environments under an accelerated cycling scenario to simulate ten years of residential use in less than a year of testing (Baxter and Linkous 2002). A second group of 18 similar units was delivered to ORNL for field-testing. Data received on 16 units installed in homes are also described in the report. The following table, from that report, summarizes the efficiencies (COPs) and savings achieved by those test units.

\begin{tabular}{|l|l|r|r|r|r|r|r|r|r|r|}
\hline \multicolumn{1}{|c|}{ City } & State & $\begin{array}{r}\text { Cents } \\
\text { per } \\
\text { kWh }\end{array}$ & Cond (A) & Gal & kBtu & kWh & COP & $\begin{array}{r}\text { kWh } \\
\text { Savings }\end{array}$ & \% Savings & \$ Savings \\
\hline Knoxville & TN & 5.81 & $\mathrm{~N}$ & 648 & 346 & 55.2 & 1.84 & 62.7 & 53.2 & 3.64 \\
\hline Verbena & AL & 5.29 & $\mathrm{~F}$ & 794 & 388 & 60.8 & 1.87 & 60.2 & 49.7 & 3.18 \\
\hline East Hampton & $\mathrm{CT}$ & 9.64 & $\mathrm{~N}$ & 511 & 310 & 44.3 & 2.05 & 56.7 & 56.1 & 5.46 \\
\hline Seattle & $\mathrm{WA}$ & 8.65 & $\mathrm{~N}$ & 778 & 397 & 74.3 & 1.57 & 52.2 & 41.3 & 4.51 \\
\hline Pensacola & $\mathrm{FL}$ & 6.40 & $\mathrm{~N}$ & 611 & 280 & 39.2 & 2.09 & 51.0 & 56.5 & 3.26 \\
\hline Wake Forest & $\mathrm{NC}$ & 8.98 & $\mathrm{~N}$ & 455 & 231 & 33.5 & 2.02 & 46.1 & 57.9 & 4.14 \\
\hline Gainesville & $\mathrm{GA}$ & 6.89 & $\mathrm{~N}$ & 411 & 210 & 30.4 & 2.02 & 43.8 & 59.0 & 3.01 \\
\hline Danielsville & $\mathrm{GA}$ & 6.89 & $\mathrm{~F}$ & 430 & 235 & 28.2 & 2.44 & 43.5 & 60.7 & 3.00 \\
\hline Melbourne & $\mathrm{FL}$ & 7.00 & $\mathrm{~N}$ & 499 & 179 & 23.8 & 2.21 & 38.8 & 62.0 & 2.72 \\
\hline Douglas & $\mathrm{AL}$ & 5.90 & $\mathrm{~N}$ & 443 & 228 & 35.7 & 1.87 & 38.5 & 51.9 & 2.27 \\
\hline Milton & $\mathrm{FL}$ & 6.40 & $\mathrm{~N}$ & 451 & 216 & 33.2 & 1.91 & 37.1 & 52.8 & 2.38 \\
\hline Madison & $\mathrm{SD}$ & 4.84 & $\mathrm{~F}$ & 309 & 180 & 24.7 & 2.14 & 35.9 & 59.3 & 1.74 \\
\hline Lenoir City & $\mathrm{TN}$ & 5.81 & $\mathrm{~S}$ & 502 & 219 & 39.1 & 1.64 & 32.2 & 45.2 & 1.87 \\
\hline Smithville & $\mathrm{TX}$ & 7.00 & $\mathrm{~F}$ & 375 & 148 & 22.0 & 1.97 & 29.6 & 57.4 & 2.07 \\
\hline Conyers & $\mathrm{GA}$ & 6.89 & $\mathrm{~N}$ & 305 & 126 & 17.1 & 2.16 & 26.9 & 61.1 & 1.85 \\
\hline Cromwell & $\mathrm{CT}$ & 9.64 & $\mathrm{~S}$ & 270 & 135 & 18.4 & 2.15 & 25.6 & 58.1 & 2.46 \\
\hline & & & & & & & & & & \\
\hline
\end{tabular}

(A) Location of Unit: $\mathrm{N}=$ non-conditioned, $\mathrm{F}=$ fully-conditioned, $\mathrm{S}=$ semi-conditioned

The following discussion is taken from the Murphy and Tomlinson study of September 2002.

"No effort was made to "preselect" locations within each house for the HPWH. Sites were selected to cover the range for electric water heater locations.

"Over the first year of the study, we found that, on average, the HPWH reduced the electric energy needed for water heating by $55 \%$. The electric energy savings ranged from as high as $62 \%$ for a unit located in a Florida garage to as low as $41 \%$ for a unit located in a basement in Washington State. These are reductions in the total electric energy consumption of the water heater, and in the case of the HPWH, include energy used by the compressor, controls and any use of backup resistance heating elements.” 
The report summarizes that, as demonstrated by the field tests, the "drop-in" design can work effectively and efficiently in all of the tested locations "including garages, basements, and utility rooms." The climate (heating vs. cooling demand) and the efficiency of the heating or cooling system used affect the HPWH's energy-saving ability when it is located in a conditioned space.

In the market-adoption analysis of this study (phase 1), the two primary barriers to market penetration were found to be price (as compared to or in addition to a standard water heater) and product reliability. Many early products were deployed before proper field testing. Adjustments have been made to ECR and Nyle products; however, some utilities have already formed perceptions of the product. In California, the ECR unit is undergoing additional field-testing; at Oak Ridge National Laboratory (ORNL) in Tennessee, the Nyle units are being tested.

Price is a difficult issue. Typical first cost for early HPWH models was $\$ 1400$ or more for a complete installation versus $\$ 400-\$ 450$ for an electric water heater. Depending on installation conditions, payback periods for the incremental cost can be as little as two years (CEE Market Transformer News 2002). Until a significant market has developed for the HPWHs, their price cannot be significantly lowered.

Furthermore, the product will not be picked up by large "do-it-yourself" stores, it will not receive "EnergyStar" labeling, and it will not be widely marketed. 